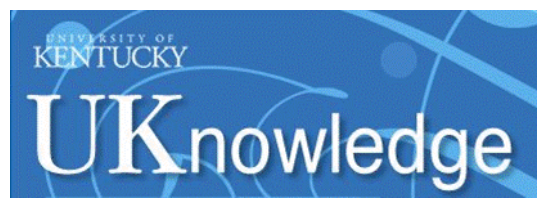

University of Kentucky

UKnowledge

\title{
Jurisdiction Under the Foreign Sovereign Immunities Act for Nazi War Crimes of Plunder and Expropriation
}

\author{
Michael D. Murray \\ University of Kentucky Rosenberg College of Law, michael.murray1@uky.edu
}

Follow this and additional works at: https://uknowledge.uky.edu/law_facpub

Part of the Jurisdiction Commons

Right click to open a feedback form in a new tab to let us know how this document benefits you.

\section{Repository Citation}

Murray, Michael D., "Jurisdiction Under the Foreign Sovereign Immunities Act for Nazi War Crimes of Plunder and Expropriation" (2004). Law Faculty Scholarly Articles. 662.

https://uknowledge.uky.edu/law_facpub/662

This Article is brought to you for free and open access by the Law Faculty Publications at UKnowledge. It has been accepted for inclusion in Law Faculty Scholarly Articles by an authorized administrator of UKnowledge. For more information, please contact UKnowledge@lsv.uky.edu. 


\section{Jurisdiction Under the Foreign Sovereign Immunities Act for Nazi War Crimes of Plunder and Expropriation}

\section{Notes/Citation Information}

Michael D. Murray, Jurisdiction Under the Foreign Sovereign Immunities Act for Nazi War Crimes of Plunder and Expropriation, 7(2) N.Y.U. J. Legis. \& Pub. Pol'y 223-286 (2004). 


\title{
JURISDICTION UNDER THE FOREIGN SOVEREIGN IMMUNITIES ACT FOR NAZI WAR CRIMES OF PLUNDER AND EXPROPRIATION
}

\author{
Michael D. Murray*
}

I.

\section{INTRODUCTION}

Six masterpieces of the famous Austrian painter Gustav Klimt are missing from Maria Altmann's home because they were stolen by the Nazis in the period immediately preceding and during World War II. ${ }^{1}$ Today, the paintings reside in the Austrian Gallery, an agency and instrumentality of the Republic of Austria-the same place where the paintings were sent by agents of the Third Reich who looted the property of Ms. Altmann's uncle, a Jewish sugar merchant named Ferdinand Bloch. ${ }^{2}$ Austria had been annexed by Nazi Germany prior to these events. Jews like Ms. Altmann's family were targeted for organized theft of their private property, including valuable works of art, in contravention of the international laws of war. ${ }^{3}$

Claims in United States courts for recovery of property stolen, looted, or expropriated in wartime encounter many procedural hurdles. ${ }^{4}$ When the property lies in the hands of the government of a

* Visiting Assistant Professor of Law, University of Illinois College of Law, Urbana-Champaign. The author gratefully acknowledges the comments and input of Professors James Pfander and Thomas Ginsburg of the University of Illinois College of Law, and Professor Richard Seamon of the University of South Carolina School of Law, and the helpful advice of Professors Richard Kaplan, Jay Kesan, and Richard McAdams, all of the University of Illinois College of Law. The author also gratefully acknowledges the research and assistance of David Wissbroecker, J.D. 2003, University of Illinois College of Law.

1. Altmann v. Republic of Austria, 142 F. Supp. 2d 1187, 1192 (C.D. Cal. 2001) (Altmann I), aff'd, 317 F.3d 954 (9th Cir. 2002) (Altmann II), cert. granted, 124 S. Ct. 46 (2003).

2. Id. at 1193 .

3. Id. at 1192 n. 4 .

4. Even straightforward claims involving the rights to a single work of art may encounter complex choice of law and conflicts of law issues involving the determination and application of the appropriate statute of limitations and substantive law, and procedural complexities involving service of process and discovery. See, e.g., United 
foreign nation or one of the nation's agencies and instrumentalities, a primary hurdle is the issue of jurisdiction over the sovereign. The Foreign Sovereign Immunities Act (FSIA) 5 provides the exclusive basis for jurisdiction in United States courts over civil actions against foreign nations and their agencies and instrumentalities. ${ }^{6}$ Sovereign nations traditionally have waived the jurisdiction of their courts with regard to suits arising from actions undertaken by foreign sovereigns and their agencies as a matter of customary international law. ${ }^{7}$ This granting of immunity from suit by one nation to another is a matter of international comity and grace, ${ }^{8}$ similar to the extension by nations of diplomatic immunity, in which nations grant immunity from their criminal laws to diplomats acting within the scope of their official duties. ${ }^{9}$

The United States follows the restrictive view of sovereign immunity, which does not automatically immunize a foreign sovereign from suit arising from actions of the sovereign nation or its instrumentalities that are equated with the actions of "private" parties, as opposed to "public" actions of a sovereign. ${ }^{10}$ Within that definition of "private" conduct are actions involving the taking of property in viola-

States v. Portrait of Wally, 105 F. Supp. 2d 288 (S.D.N.Y. 2000) (Wally I); United States v. Portrait of Wally, No. 99 Civ. 9940 (MBM), 2000 WL 1890403 (S.D.N.Y. Dec. 28, 2000) (Wally II); United States v. Portrait of Wally, No. 99 Civ. 9940 (MBM), 2002 WL 553532 (S.D.N.Y. Apr. 12, 2002) (Wally III).

5. Pub. L. No. 94-583, 90 Stat. 2891 (1976) (codified as amended at 28 U.S.C. $\S \S 1602-1611(2000))$.

6. See Argentine Republic v. Amerada Hess Shipping Corp., 488 U.S. 428, 443 (1989). The FSIA amended Title 28 of the United States Code, removing the portion of $\$ 1332$ (a) which had granted federal courts diversity jurisdiction over claims involving citizens of a state and a foreign state. 28 U.S.C. $\$ 1332$ (a) (2000). The new provision, $\S 1330$ (a), provides for "original jurisdiction without regard to amount in controversy of any nonjury civil action against a foreign state . ." 28 U.S.C. $\S 1330$ (a) (2000). Section 1332(a)(4) of Title 28 still provides jurisdiction over a suit in which a foreign state is a plaintiff against citizens of a state or of different states in which the amount in controversy requirement is met. The FSIA also amended the removal jurisdiction statute, 28 U.S.C. $\$ 1441$, to provide for removal to federal court of actions brought against foreign states in state court. 28 U.S.C. $\S 1441$ (d) (2000).

7. See Restatement (ThIRD) of Foreign Relations Law of the United STATES $\S \S 451-455, \S 464$ (1987) (hereinafter Restatement). "The immunity of a state from the jurisdiction of the courts of another state is an undisputed principle of customary international law." Id. at pt. IV, ch. 5 , subch. A, introductory note.

8. See Dole Food Co. v. Patrickson, 123 S. Ct. 1655, 1663 (2003); Verlinden B.V. v. Central Bank of Nig., 461 U.S. 480, 486 (1983).

9. See Restatement, supra note $7, \S 464$.

10. Id. $\$ 451 \mathrm{cmt}$. a; 14 A Charles Alan Wright et al., Federal Practice and Procedure $\$ 3662$ (3d ed. 1998). 
tion of international law ${ }^{11}$ or actions that amount to commercial dealings, such as buying, selling and lending, that are equivalent to the commercial activity of private parties. ${ }^{12}$ The restrictive theory of sovereign immunity has been practiced by a number of sovereign nations since the early part of the twentieth century, ${ }^{13}$ but some uncertainty exists as to when the United States first officially announced its adherence to the restrictive doctrine. Many courts and scholars have traced the official adoption to what has come to be called the Tate Letter, which was written in 1952.14 In fact, there is a fundamental misconception in the present jurisprudence of certain United States courts that the Tate Letter effected a complete turnabout from a system of absolute sovereign immunity to one of restrictive sovereign immunity. ${ }^{15}$ This reading of the Tate Letter, however, simply is unsupported by the cases.

It is my position that the principles of the restrictive theory were adopted and applied by United States courts early in the nineteenth century, starting with three landmark decisions of the Marshall Court, ${ }^{16}$ and that only for a brief period from 1926 to 1938 did the United States Supreme Court send a mixed message concerning the absolute theory of sovereign immunity that contrasted with the more restrictive message being espoused by the State Department and executive branch during the same period.

Currently, courts are addressing the question of the propriety of the exercise of jurisdiction under the FSIA for claims arising from war crimes that arose prior to the effective date of the statute, January 1 ,

11. 28 U.S.C. $\S 1605(a)(3)$ (2000). The rationale for treating acquisitions of property that violate international law as private acts is the legal presumption that sovereign nations follow customary and conventional international law as a matter of course. See West v. Multibanco Comermex, S.A., 807 F.2d 820, 826 (9th Cir. 1987). Therefore, when a state has engaged in conduct that violates these principles, it is regarded as not having behaved in the manner of a sovereign, and thus is not entitled to the privileges afforded to sovereign nations. Id.

12. 28 U.S.C. $\S 1605(a)(3)(2000)$

13. RestATEMENT, supra note 7 , pt. IV, ch. 5 , subch. A, introductory note.

14. Letter from Jack B. Tate, Acting Legal Adviser, Department of State, to Philip B. Perlman, Acting Attorney General (May 19, 1952), in DeP't Sr. Bull., June 23, 1952, at 984-85 [hereinafter Tate Letter of 1952].

15. See, e.g., Hwang Geum Joo v. Japan, 332 F.3d 679, 682 (D.C. Cir. 2003) ("Prior to 1952, the courts of the United States generally followed the doctrine of 'absolute immunity' . . . that is, the courts almost always held a foreign sovereign immune from suit ... In 1952 the United States adopted the doctrine of "restrictive immunity, as set out in the Tate Letter and later codified in the FSIA." (internal citations omitted)).

16. The Schooner Exchange v. McFaddon, 11 U.S. (7 Cranch) 116 (1812); The Santissima Trinidad, 20 U.S. (7 Wheat.) 283, 353 (1822); Bank of the United States v. Planters' Bank of Ga., 22 U.S. (9 Wheat.) 904 (1824). 
1977, and prior to the Tate Letter in 1952. ${ }^{17}$ Part of what is at stake is jurisdiction over wartime plunder and expropriation claims arising from the conduct of the German belligerent forces and their agents and instrumentalities during the Holocaust and in World War II that violated international law. Claims have been brought in United States courts for recovery of stolen art work ${ }^{18}$ as well as confiscated real and personal property. ${ }^{19}$

There is a circuit split among the United States Courts of Appeals regarding the exercise of jurisdiction under the FSIA for claims arising prior to 1952, several of which involve World War II-era war crimes. ${ }^{20}$ The lines are drawn around four issues regarding the application of the FSIA: (1) whether the FSIA is a jurisdictional statute, allocating or affirming the power of courts to hear certain cases without regard to whether the conduct, causes of action, and substantive defenses to the action arose prior to its effective date or prior to 1952; (2) whether the FSIA is a procedural statute that applies to actions arising from operative facts that occurred before the effective date of the statute and before 1952 because it does not affect antecedent rights of the parties and thus is not retroactive; (3) if the application of the FSIA to pre-enactment conduct or to conduct predating the 1952 announcement of the United States' adherence to the restrictive theory of sovereign immunity does in fact affect substantive rights of state parties, namely rights to sovereign immunity under U.S. law, whether the retroactive application of the statute was clearly indicated and intended by Congress based on the language and design of the FSIA; and (4) whether the conduct of the Nazi regime and its agencies and

17. See sources cited infra notes $18 \& 20$. The most comprehensive treatment of the issue of retroactive application of the FSIA to pre-1952 conduct is Adam K.A. Mortara, Comment, The Case Against Retroactive Application of the Foreign Sovereign Immunities Act of 1976, 68 U. CHI. L. Rev. 253 (2001).

18. Altmann v. Republic of Austria, 142 F. Supp. 2d 1187 (C.D. Cal. 2001) (Altmann I), aff'd, 317 F.3d 954 (9th Cir. 2002) (Altmann II), cert. granted, 124 S. Ct. 46 (2003).

19. Haven v. Rzeczpospolita Polska (Republic of Pol.), 68 F. Supp. 2d 943 (N.D. Ill. 1999), aff'd, 215 F.3d 727 (7th Cir. 2000); Bernstein v. N.V. NederlandscheAmerikaansche Stoomvaart-Maatschappij, 173 F.2d 71 (2d Cir. 1949), modified by 210 F.2d 375 (2d Cir. 1954) (per curiam).

20. Compare Altmann II, 317 F.3d 954 (finding that jurisdiction over World War II expropriation claims is appropriate under FSIA), and Haven, 215 F.3d 727 (same), with Joo, 332 F.3d 679 (holding that jurisdiction over "comfort women's" claims from era of Japanese aggression, 1931-45, is inappropriate under FSIA), and Carl Marks \& Co. v. Union of Soviet Socialist Republics, 841 F.2d 26 (2d Cir. 1988) (finding that jurisdiction over claims arising from 1916 bond issuance is inappropriate under FSIA), and Jackson v. People's Republic of China, 794 F.2d 1490 (11th Cir. 1986) (finding that jurisdiction over claims arising from 1911 bond issuance is inappropriate under FSIA). 
instrumentalities in World War II should have defeated the expectations of these state parties that they would receive immunity from prosecution in foreign courts, thus refuting the claim that retroactive application of the FSIA actually violates substantive rights under customary international law.

This article addresses each of these issues regarding the application of jurisdiction under the FSIA to World War II and other pre1952 war crimes, including claims involving expropriation and plunder of personal property, and concludes that none of these issues prevents the exercise of jurisdiction under the FSIA for resolution of these claims in United States courts. Part II discusses the history of the doctrine of sovereign immunity in the United States prior to the enactment of the FSIA, with particular reference to the development of the restrictive theory of sovereign immunity. Part III discusses the structure and purpose of the Foreign Sovereign Immunities Act and the expropriation exception. Part IV discusses whether the FSIA is a jurisdictional statute. Part V discusses whether the FSIA is a procedural statute that applies to pre-effective date and pre-1952 conduct without affecting the antecedent rights of the parties. Part VI considers whether the retroactive application of the statute was clearly indicated and intended by Congress, if in fact the application of the FSIA to pre-enactment conduct or to pre-1952 conduct does affect substantive rights of state parties to sovereign immunity under U.S. law. Part VII discusses whether nations implicated in World War II-era war crimes should have expected immunity from prosecution in foreign courts, thus further refuting the claim that retroactive application of the FSIA actually violates substantive rights under customary international law.

\section{II.}

\section{SOVEREIGN IMMUNITY IN THE United States}

Examining the early development of foreign sovereign immunity law in the United States reveals that the watershed opinions of the Marshall Court established a much more restrictive view of sovereign immunity than recent court decisions would indicate. Courts routinely trace the origin of foreign sovereign immunity to The Schooner Exchange, ${ }^{21}$ but mistakenly believe that this 1812 case inaugurated a regime of absolute immunity, when in truth the Marshall Court's view was more attuned to a restrictive theory. In fact, except for a brief period from 1926 to 1938 , the history of cases from the Marshall

21. 11 U.S. (7 Cranch) 116 (1812). 
Court to the Tate Letter demonstrates that absolute immunity was not afforded to every foreign sovereign, and especially not to unfriendly foreign sovereigns.

The misconception of the American doctrine of sovereign immunity begins with Chief Justice John Marshall's opinion in The Schooner Exchange. It is widely agreed that The Schooner Exchange opinion set down the basic principles that were carried through to the Tate Letter and the FSIA. ${ }^{22}$ However, the view that Chief Justice Marshall's opinion had created an American doctrine of absolute sovereign immunity is a misinterpretation. In fact, The Schooner Exchange is quite limited in its holding, and reflects a fairly modern and restrictive view of sovereign immunity-much more modern and restrictive than the absolute immunity theory improperly attributed to the case by modern authorities.

The sections that follow discuss the history leading up to The Schooner Exchange, which also demonstrates a restrictive view of immunity, and the other two cases of the Marshall Court, Santissima Trinidad $^{23}$ and Planters' Bank, ${ }^{24}$ that complete the nineteenth century restrictive doctrine of immunity laid down by the Marshall Court. As will be seen, the proponents of an application of the Foreign Sovereign Immunities Act to conduct predating the Tate Letter may rely on Chief Justice Marshall for the following propositions: (1) that foreign sovereign immunity in the United States has been limited from the start, as Chief Justice Marshall's explanation of the distinctions to be drawn between private conduct and public conduct is much more attuned to the restrictive view of sovereign immunity than the absolute view; (2) that sovereign immunity is a privilege afforded to foreign states as matter of comity, not a right possessed by the foreign sovereign; (3) that sovereign immunity is not afforded to hostile nations to the same degree as it is afforded to friendly nations; (4) that the expectations of such a right are affected by customary international law defined by common usage (state practice) and by common opinion growing out of that usage (opinio juris); and (5) that the privilege may be removed by the territorial sovereign simply by giving notice that it will exercise jurisdiction over foreign sovereigns.

22. See discussion infra Parts II.B, II.G-H.

23. 20 U.S. ( 7 Wheat.) 283 (1822).

24. Bank of the United States v. Planters' Bank of Ga., 22 U.S. (9 Wheat.) 904 (1824). 


\section{A. Sovereign Immunity in the United States Prior to The Schooner Exchange}

The doctrine of sovereign immunity was recognized and applied by United States courts from the very beginning of the republic. As early as 1781, the Admiralty Court of Pennsylvania recognized the doctrine that a court must abstain from exercising jurisdiction over an action involving a vessel owned by and operated in the service of a foreign nation. ${ }^{25}$ In the beginning, the courts recognized that the doctrine was not absolute. ${ }^{26}$ In fact, in 1798 , a federal court held that a ship engaged in the commercial enterprise of "prize hunting" under the grant of a letter of marque of a foreign sovereign was subject to suit in United States courts because its activity was private and commercial, unlike that of a true warship in direct service of a sovereign nation. ${ }^{27}$

The citizens of the new republic looked with suspicion on the doctrine of sovereign immunity, associating it with other abuses and injustices of the Crown from which they had just fought to gain their independence. ${ }^{28}$ In the colonies, belief in the immunity of the sovereign was by no means universal. ${ }^{29}$ Many colonies disclaimed sovereign immunity in their charters, and none included a general grant of sovereign immunity in its constitution upon winning independence from England in 1776. ${ }^{30}$

25. Moitez v. The South Carolina, 17 F. Cas. 574 (Adm. Pa. 1781) (No. 9,697).

26. See David J. Bederman, Admiralty and the Eleventh Amendment, 72 Notre DAmE L. Rev. 935, 940 (1997). American lawyers and jurists at the start of the republic can be expected to have been steeped in the English common law tradition, which did not afford the Crown absolute protection from suit. Id. at 939-40. While it had been widely recognized that the King could not be sued in his own courts, including the High Court of Admiralty in London, this was largely modified by the Petition of Right and monstrans de droit, forms of action which permitted proceedings against the Crown. Id. at 939. Certain kinds of admiralty proceedings could be brought against the Crown in the High Court of Admiralty, most notably prize cases in which the court considered the propriety, under international law, of the capture of enemy vessels or cargo. Id. at $939-40$.

27. Ellison v. The Bellona, 8 F. Cas. 559 (D.S.C. 1798) (No. 4,407).

28. Bederman, supra note 26 , at 940 . My discussion here is a fairly simplistic summary of a complicated history. For a much more thorough discussion of this history, see James E. Pfander, Rethinking the Supreme Court's Original Jurisdiction in State-Party Cases, 82 CAL. L. Rev. 555, 578-87 (1994); Peter J. Smith, States as Nations: Dignity in Cross-Doctrinal Perspective, 89 VA. L. Rev. 1, 28-36 (2003).

29. Bederman, supra note 26, at 940 (quoting Calvin R. Massey, State Sovereignty and the Tenth and Eleventh Amendments, 56 U. CHI. L. Rev. 61, 89 (1989)). See also Doyle Mathis, The Eleventh Amendment: Adoption and Interpretation, $2 \mathrm{GA}$. L. REv. 207, 209 (1968); Pfander, supra note 28, at 578-80; Smith, supra note 28, at 28-36.

30. Bederman, supra note 26 , at 940 ; Massey, supra note 29 , at 89. 


\section{B. The Schooner Exchange Case}

In 1812, Chief Justice John Marshall crafted the American doctrine of sovereign immunity in The Schooner Exchange v. McFaddon, ${ }^{31}$ which was the starting point of foreign sovereign immunity analyses in United States courts. The Schooner Exchange arose from the seizure and attachment of a public vessel of war in the service of Napoleon, who was then Emperor of France and King of Italy. ${ }^{32}$ Apparently, the French had previously seized the American-owned ship, the Schooner Exchange, in the French-controlled Spanish port of St. Sebastians and expropriated and outfitted it as a war vessel in the service of the French sovereign. ${ }^{33}$ When weather and distress forced the ship to call at Philadelphia, its original American owners libeled it and caused an attachment to issue against it. ${ }^{34}$

The litigants characterized the ship as a vessel of war in direct service of the French sovereign, rather than one engaged in commerce or trade. ${ }^{35}$ The report of the case specifically notes the allegation that the ship "did not come to trade. There was no implied waiver of the peculiar immunities of a public vessel,"36 indicating the perception of the litigants and the United States Attorney ${ }^{37}$ for the District of Pennsylvania (acting on behalf of the executive branch to convey a "suggestion" regarding the status of the vessel) that engaging in private, commercial activity would affect the ship's immunity from jurisdiction and court process.

The United States Attorney, arguing in favor of relinquishing jurisdiction over the vessel, stated:

We do not ... deny the right of a nation to change the public law as to foreign nations, upon giving notice. We may forbid the entrance of their public ships, and punish the breach of this prohibition by forfeiture, nor do we deny the obligation of a foreign sovereign to conform to pre-existing laws, as to offences-and as to the acquisition of property; nor his liability for his private debts and contracts. So if a sovereign descend from the throne and become a merchant, he submits to the laws of the country. If he contract private debts,

31. 11 U.S. (7 Cranch) 116, 123 (1812).

32. Id. at $117-18$.

33. Id. at 117 .

34. Id. at 118 .

35. Id. at 122 .

36. Id.

37. Mr. A.J. Dallas's actual title was Attorney of the United States, for the District of Pennsylvania. See id. at 117-18. This article uses the now-equivalent term "United States Attorney" for the convenience of modern readers. 
his private funds are liable. So if he charter a vessel, the cargo is liable for the freight. ${ }^{38}$

The government's attorney's delineation of the boundaries of sovereign immunity sounds startlingly modern, as it appears virtually identical to the restrictive theory of sovereign immunity in the twentieth century. ${ }^{39}$ His argument first reflects the modern understanding that state practice defines customary international law and that a state may change the law by giving notice of its intent to pursue a different course. ${ }^{40}$ Similarly, he asserts that a foreign sovereign engaged in private acts-criminal offenses, the purchasing and ownership of property, trade and commerce, and entry into private debts and contractsis amenable to the proscription and enforcement of a territorial sovereign's laws. ${ }^{41}$ The theory asserted here is one of implied consent and submission to the laws of the territorial sovereign. The United States Attorney continued:

Such consent is implied where the municipal law, previously provides and changes the law of nations-where it regulates tradewhere it defines and punishes crimes, and where it fixes the tenure of property real or personal. But it cannot be implied where the law of nations is unchanged-nor where the implication is destructive of the independence, the equality, and dignity of the sovereign ....

There is then no municipal law, nor any practical construction by the executive, the legislative, or the judicial department of our government, which authorizes the jurisdiction now claimed, we can only have recourse to the law of nations to try the validity of that claim. That law requires the consent of the sovereign, either express or implied, before he can be subjected to a foreign jurisdiction. There is no express assent of a foreign sovereign to the jurisdiction over his prerogative. The distinction is between his private acts, and his acts as sovereign, and between his private and his public property. 42

This argument distinguishes between private and public conduct and, likewise, the proper exercise of jurisdiction over vessels engaged

38. Id. at 123 (citation omitted).

39. See Restatement, supra note $7, \S 451 \mathrm{cmt}$. a.

40. The Schooner Exchange, 11 U.S. (7 Cranch) at 123.

41. Id.

42. Id. at 123, 125 (citations omitted). The United States Attorney laid out three specific areas where implied consent to jurisdiction existed under customary international law: (1) trade; (2) acquisition of real or personal property in the territory of the other state; and (3) offenses against the laws of the territorial state. Jurisdiction, however, does not apply to the person of the sovereign himself, to his ambassador, or to his armies and navies passing through the territory of the other state. See id. at 125. 
in private activities for a foreign state and improper exercise of jurisdiction over public vessels-in this case, a warship-of a foreign sovereign, ${ }^{43}$ a principle already recognized by United States courts in the eighteenth century cases of The South Carolina and The Bellona. ${ }^{44}$

The U.S. Attorney and U.S. Attorney General further emphasized that because the United States and France enjoyed a state of peace and amity, ${ }^{45}$ it would prove desirous not to embarrass the independence, equality, and dignity of the foreign sovereign by dragging it before a municipal tribunal. ${ }^{46}$ Though this "embarrassment" factor received little emphasis in Chief Justice Marshall's opinion, ${ }^{47}$ later courts interpreted it as a public policy justification for courts to abstain from jurisdiction so as not to embarrass the political branches of the United States, and in particular the State Department, in the conduct of foreign policy. ${ }^{48}$

The U.S. Attorney General's argument asserted that the exercise of jurisdiction raised a non-justiciable political question, beyond the Constitution's grant of jurisdiction over suits between a "State, or the Citizens thereof, and foreign States, Citizens or Subjects." $49 \mathrm{He}$ argued:

When wrongs are inflicted by one nation upon another, in tempestuous times, they cannot be redressed by the judicial department. ... The right to demand redress belongs to the executive depart-

43. Id. at 123 .

44. See Ellison v. The Bellona, 8 F. Cas. 559, 559 (D.S.C. 1798) (No. 4,407); Moitez v. The South Carolina, 17 F. Cas. 574, 574 (Adm. Pa. 1781) (No. 9,697).

45. The rights of a belligerent nation to sovereign immunity are quite different. In fact, throughout much of the United States history, courts applied the doctrine that the government may seize the property of a foreign belligerent or that of a domestic entity in rebellion without compensation, and the courts are without jurisdiction to review such actions. See Deutsch-Australische Dampfschiffs Gesellschaft v. United States, 59 Ct. Cl. 450 (1924); Herrera v. United States, 222 U.S. 558, 573-74 (1911); Ribas y Hijo v. United States, 194 U.S. 315, 323 (1903); Miller v. United States, 78 U.S. 268, 268-69 (1870).

46. The Schooner Exchange, 11 U.S. (7 Cranch) at 131-32, 134 (1812).

47. See id. at 146.

48. See, e.g., Nat'l City Bank of N.Y. v. Republic of China, 348 U.S. 356, 361 (1954); Republic of Mexico v. Hoffman, 324 U.S. 30, 34 (1944).

49. U.S. ConsT. art. III, \& 2, cl. 1; The Schooner Exchange, 11 U.S. (7 Cranch) at 132. The Attorney General's political question argument would later be embodied in the act of state doctrine, regarding the justiciability of the acts of foreign sovereigns. This doctrine differs from the concept of sovereign immunity in that sovereign immunity concerns jurisdiction over the person or property of a foreign sovereign and power over the subject matter of a dispute that involves a foreign sovereign as a party. See First Nat'l City Bank v. Banco Nacional de Cuba, 406 U.S. 759, 765-66 (1972) (plurality opinion). Regarding the act of state doctrine in U.S. courts, see generally Banco Nacional de Cuba v. Sabbatino, 376 U.S. 398 (1964); Underhill v. Hernandez, 168 U.S. 250 (1897). 
ment, which alone represents the sovereignty of the nation in its intercourse with other nations.

The simple fact in this case is, that an individual is seeking, in the ordinary course of justice, redress against the act of a foreign sovereign. But the rights of a foreign sovereign cannot be submitted to a judicial tribunal. ...

We claim for this vessel, an immunity from the ordinary jurisdiction, as extensive as that of an ambassador, or of the Sovereign himself; but no further. If she attempt violence, she may be restrained.

The constitution of the United States decides nothing; it only provides a tribunal, if a case can by possibility exist. . . .

Sovereigns are equal. It is the duty of a sovereign, not to submit his rights to the decision of a co-sovereign. He is the sole arbiter of his own rights. He acknowledges no superior, but God alone. To his equals, he shows respect, but not submission.

This vessel is not the ordinary property of a sovereign.-It is his national property - a public ship of war duly commissioned. There is no difference in principle between such a vessel, and an army passing through the territory. She has the same rights. She has your permission to pass, and you are bound to give her all necessary immunities. ${ }^{50}$

In response to these arguments, Chief Justice Marshall followed the U.S. Attorney's line of thought and decided the case on jurisdictional grounds, stating:

The jurisdiction of courts is a branch of that which is possessed by the nation as an independent sovereign power.

The jurisdiction of the nation within its own territory is necessarily exclusive and absolute. It is susceptible of no limitation, not imposed by itself. Any restriction upon it, deriving validity from an external source, would imply a diminution of its sovereignty to the extent of the restriction, and an investment of that sovereignty, to the same extent in that power which could impose such restriction. All exceptions, therefore, to the full and complete power of a nation within its own territories, must be traced up to the consent of the nation itself. They can flow from no other legitimate source. ${ }^{51}$

Chief Justice Marshall reviewed the tenets of customary international law that called upon states to relax their own territorial jurisdiction in dealings with foreign states as matter of comity, grace and good offices:

50. The Schooner Exchange, 11 U.S. (7 Cranch) at 132-33, 134.

51. Id. at 136. 
The world being composed of distinct sovereignties, possessing equal rights and equal independence, whose mutual benefit is promoted by intercourse with each other, and by an interchange of those good offices which humanity dictates and its wants require, all sovereigns have consented to a relaxation in practice, in cases under certain peculiar circumstances, of that absolute and complete jurisdiction within their respective territories which sovereignty confers.

This full and absolute territorial jurisdiction being alike the attribute of every sovereign, and being incapable of conferring extraterritorial power, would not seem to contemplate foreign sovereigns nor their sovereign rights as its objects. One sovereign being in no respect amenable to another; and being bound by obligations of the highest character not to degrade the dignity of his nation, by placing himself or its sovereign rights within the jurisdiction of another, can be supposed to enter a foreign territory only under an express license, or in the confidence that the immunities belonging to his independent sovereign station, though not expressly stipulated, are reserved by implication, and will be extended to him.

This perfect equality and absolute independence of sovereigns, and this common interest impelling them to mutual intercourse, and an interchange of good offices with each other, have given rise to a class of cases in which every sovereign is understood to wave [sic] the exercise of a part of that complete exclusive territorial jurisdiction, which has been stated to be the attribute of every nation. ${ }^{52}$

Chief Justice Marshall also reviewed three settled instances in the law where the sovereign nature of the defendant led to a withholding of jurisdiction: (1) the exemption of the person of the sovereign from arrest or detention within a foreign territory; (2) the immunity of ambassadors and foreign ministers; and (3) the territorial sovereign allowing foreign troops to pass through his dominions. ${ }^{53}$ Marshall found the problem in the case at hand-exercise of in rem jurisdiction over a foreign warship alleged originally to have been United States citizens' private property-to be much more vexing. He first considered the argument that the situation paralleled that of an ambassador who has committed crimes and thereby subjected himself to the jurisdiction of the territorial sovereign, but did not find the argument dispositive:

In what cases a minister, by infracting the laws of the country in which he resides, may subject himself to other punishment than

52. Id. at $136-37$.

53. Id. at $137-39$. 
will be inflicted by his own sovereign, is an inquiry foreign to the present purpose. If his crimes be such as to render him amenable to the local jurisdiction, it must be because they forfeit the privileges annexed to his character; and the minister, by violating the conditions under which he was received as the representative of a foreign sovereign, has surrendered the immunities granted on those conditions; or, according to the true meaning of the original assent, has ceased to be entitled to them. ${ }^{54}$

Chief Justice Marshall then considered the situation of a territorial sovereign who allows armies to traverse his territory, and the customary and conventional international law rules regarding ships' taking refuge from distress in ports of a territorial sovereign. ${ }^{55}$ Finally, Marshall reached the narrow conclusion that where a nation has allowed its ports to be open to private and public ships of a friendly foreign sovereign, there exists a jurisdictional distinction between ships on private business and those in public service to the sovereign:

To the Court, it appears, that where, without treaty, the ports of a nation are open to the private and public ships of a friendly power, whose subjects have also liberty without special license, to enter the country for business or amusement, a clear distinction is to be drawn between the rights accorded to private individuals or private trading vessels, and those accorded to public armed ships which constitute a part of the military force of the nation.

The preceding reasoning, has maintained the propositions that all exemptions from territorial jurisdiction, must be derived from the consent of the sovereign of the territory, that this consent may be implied or expressed, and that when implied, its extent must be regulated by the nature of the case, and the views under which the parties requiring and conceding it must be supposed to act.

When private individuals . . . or when merchant vessels enter for the purposes of trade, it would be obviously inconvenient and dangerous to society, and would subject the laws to continual infraction, and the government to degradation, if such individuals or merchants did not owe temporary and local allegiance, and were not amenable to the jurisdiction of the country. Nor can the foreign sovereign have any motive for wishing such exemption. . . . Consequently there are powerful motives for not exempting persons of this description from the jurisdiction of the country in which they are found, and no one motive for requiring it. The implied license,

54. Id. at 139. The acknowledgement that the diplomatic immunity of ambassadors, though recognized by "all civilized nations," is not absolute is noteworthy, as it provides a light for the proper interpretation of the holding of the case. Id. at 138 .

55. Id. at $139-41$. 
therefore, under which they enter can never be construed to grant such exemption.

But in all respects different is the situation of a public armed ship. She constitutes a part of the military force of her nation, acts under the immediate and direct command of the sovereign, is employed by him in national objects. He has many and powerful motives for preventing those objects from being defeated by the interference of a foreign state. Such interference cannot take place without affecting his power and his dignity. The implied license therefore under which such vessel enters a friendly port, may reasonably be construed, and it seems to the Court, ought to be construed, as containing an exemption from the jurisdiction of the sovereign, within whose territory she claims the rites of hospitality. ${ }^{56}$

The Court's explanation, in dicta, of the difference between a sovereign's private property and public property engaged in the service of the foreign state further narrowed this holding:

[I]t may safely be affirmed, that there is a manifest distinction between the private property of the person who happens to be a prince, and that military force which supports the sovereign power, and maintains the dignity and the independence of a nation. A prince, by acquiring private property in a foreign country, may possibly be considered as subjecting that property to the territorial jurisdiction, he may be considered as so far laying down the prince, and assuming the character of a private individual, but this he cannot be presumed to do with respect to any portion of that armed force, which upholds his crown, and the nation he is entrusted to govern. 57

As mentioned above, Chief Justice Marshall did not follow the U.S. Attorney General's line of thought, and instead chose to resolve the question as a jurisdictional issue under the law of sovereign immunity rather than a justiciability issue or political question issue under the developing doctrine regarding acts of state:

The arguments in favor of this opinion which have been drawn from the general inability of the judicial power to enforce its decisions in cases of this description, from the consideration, that the sovereign power of the nation is alone competent to avenge wrongs committed by a sovereign, that the questions to which such wrongs give birth are rather questions of policy than of law, that they are for diplomatic, rather than legal discussion, are of great weight, and merit serious attention. But the argument has already been drawn

56. Id. at $143-44$.

57. Id. at 145. 
to a length, which forbids a particular examination of these points. 58

More importantly for the consideration of the issue of retroactivity, Chief Justice Marshall emphasized that a territorial sovereign's withdrawal of jurisdiction over actions involving a foreign sovereign was a matter of comity and good offices extended to a fellow sovereign, not an inherent right of the foreign sovereign to such immunity. ${ }^{59}$ Furthermore, Marshall emphasized that the assumption of a foreign sovereign that it will be free from the harassment of suit in a foreign nation can be rebutted by the territorial sovereign by giving notice and acting to exercise jurisdiction, because such notice and state practice redefines customary international law:

This consent may, in some instances, be tested by common usage, and by common opinion, growing out of that usage.

A nation would justly be considered as violating its faith, although that faith might not be expressly plighted, which should suddenly and without previous notice, exercise its territorial powers in a manner not consonant to the usages and received obligations of the civilized world.

Without doubt, the sovereign of the place is capable of destroying this implication. He may claim and exercise jurisdiction either by employing force, or by subjecting such vessels to the ordinary tribunals. But until such power be exerted in a manner not to be misunderstood, the sovereign cannot be considered as having imparted to the ordinary tribunals a jurisdiction, which it would be a breach of faith to exercise. ${ }^{60}$

One of the last gestures of the Court in The Schooner Exchange was to pay regard to the practice of the executive branch of the federal government, acting through its attorney, to provide "suggestions" to the court regarding the sovereign status of the property or the foreign sovereign itself at issue in the case. ${ }^{61}$ This would prove to be a fateful invitation, as the doctrine developed wherein the Supreme Court allowed courts to exercise jurisdiction over property alleged to be the

58. Id. at 146.

59. See, e.g., id. at 143 ("[A]ll exemptions from territorial jurisdiction, must be derived from the consent of the sovereign of the territory; that this consent may be implied or expressed, and that when implied, its extent must be regulated by the nature of the case, and the views under which the parties requiring and conceding it, must be supposed to act.").

60. Id. at $136-37,146$.

61. Id. at 147 ("If this opinion be correct, there seems to be a necessity for admitting that the fact might be disclosed to the Court by the suggestion of the Attorney for the United States."). 
property of and within the sovereignty of a foreign power, if the United States Attorney acting on behalf of the executive branch refused to give a suggestion regarding the sovereignty of the nation or the immunity of the property, or was silent on the matter. ${ }^{62}$

\section{The Santissima Trinidad Case}

Jurists and scholars frequently cite The Schooner Exchange as the watershed case on foreign sovereign immunity, but The Santissima Trinidad, ${ }^{63}$ a Supreme Court case that appeared just ten years later, deserves as much attention. The Santissima Trinidad opinion, written by Justice Story (while Chief Justice Marshall still served on the Court), is as obscure as The Schooner Exchange case is famous. Like The Schooner Exchange, the case arose in the admiralty context of the arrest of a foreign vessel, but in this case, the dispute was over a "prize" claimed by litigants from opposite sides of the Spanish colonial war of independence. ${ }^{64}$ The consul of Spain alleged that two Spanish ships, the Santissima Trinidad and the St. Ander, had been pirated of their contents by two armed vessels, the Independencia del Sud and the Altravida. ${ }^{65}$ In reply, the master of the Independencia, James Chaytor, claimed that his ships were warships of the United Provinces of Rio de la Plata, the colonies in rebellion against Spain, and that he relieved the two Spanish ships of their cargo as a lawful prize under the laws of war. ${ }^{66}$ Among other objections to the Court's jurisdiction, the respondent objected to the Court's exercise of jurisdiction over the action because it involved the actions of a public ship of war, the Independencia del Sud. ${ }^{67}$ That the ship was a publicly owned and operated warship was not questioned by the Court, and the Court agreed that in rem jurisdiction over the foreign warship itself

62. See infra notes 117-120 and accompanying text.

63. 20 U.S. (7 Wheat.) 283 (1822).

64. Id. at $284-85$.

65. Id.

66. The case recounts the colorful history of the master, James Chaytor of Baltimore (also known as Don Diego Chaytor of Buenos Ayres [sic]), and his crew. Id. at 284-86. They had arranged for the American-owned ship, the Mammoth, to be outfitted and to set sail to Buenos Aires, where ownership of the vessel was transferred to the purported government of the rebellious colonies, alternatively referred to as the United Provinces of Rio de la Plata or Buenos Ayres. Id. at 286-87. There, Chaytor attempted to swear off his United States citizenship and assume citizenship and a military commission in the government of Buenos Aires. Id. at 287-88. Chaytor then set sail on a prize cruise to prey on Spanish ships. Id. at 288 . One of the prizes he claimed was the cargo of the Santissima Trinidad, and Chaytor took his cargo prize into the port of Norfolk, Virginia for safekeeping. Id. at 285-86. There, it was attached through the libel of the consul of Spain. Id. at 286.

67. Id. at $285-86$. 
would not be appropriate under The Schooner Exchange, but the Court would not accept the extension of the argument to cover the cargo seized by the warship as its prize. ${ }^{68}$ It is here that the Court clarified and extended its decision in The Schooner Exchange in ways that are relevant to the issue of restrictive sovereign immunity.

Justice Story first clarified that customary international law limited sovereign immunity to situations in which a territorial sovereign waives jurisdiction over a foreign sovereign's agents and instrumentalities who peaceably enter the territory of the territorial sovereign on public business of the foreign sovereign, under the perception and expectation that this act would not trigger the jurisdiction of the territorial sovereign's courts. ${ }^{69}$ Justice Story noted, however, that such immunity does not extend to the situation where the foreign sovereign enters the jurisdiction on personal (as opposed to public) matters, because the territorial sovereign may then exercise jurisdiction over the personal and public property of the sovereign engaged in personal activities:

In the case of the Exchange, the grounds of the exemption of public ships were fully discussed and expounded. It was there shown that it was not founded upon any notion that a foreign sovereign had an absolute right, in virtue of his sovereignty, to an exemption of his property from the local jurisdiction of another sovereign, when it came within his territory; for that would be to give him sovereign power beyond the limits of his own empire. But it stands upon principles of public comity and convenience, and arises from the presumed consent or license of nations, that foreign public ships coming into their ports, and demeaning themselves according to law, and in a friendly manner, shall be exempt from the local jurisdiction. But as such consent and license is implied only from the general usage of nations, it may be withdrawn upon notice at any time, without just offence, and if afterwards such public ships come into our ports, they are amenable to our laws in the same manner as other vessels. To be sure, a foreign sovereign cannot be compelled to appear in our Courts, or be made liable to their judgment, so long as he remains in his own dominions, for the sovereignty of each is bounded by territorial limits. If, however, he comes personally within our limits, although he generally enjoy [sic] a personal immunity, he may become liable to judicial process in the same way, and under the same circumstances, as the public ships of the nation. ${ }^{70}$

68. Id. at 351-53.

69. Id. at $336,352-53$.

70. Id. at $352-53$ (citation omitted). 
The Court emphasized that nothing may compel the appearance of a sovereign if he remains within the boundaries of his own dominions, but that the presumption does not extend to personal activities of the sovereign carried on in the territorial jurisdiction. ${ }^{71}$ Furthermore, the Court held that nothing in customary international law prevents a sovereign from appearing in the courts of another nation voluntarily, and noted that if it is deemed necessary for the sovereign to appear as a litigant to properly defend its interests as to property found within the territorial jurisdiction of another nation, so be it; the mere fact that a sovereign's appearance is necessary does not deny the local court jurisdiction:

But there is nothing in the law of nations which forbids a foreign sovereign, either on account of the dignity of his station, or the nature of his prerogative, from voluntarily becoming a party to a suit in the tribunals of another country, or from asserting there any personal, or proprietary, or sovereign rights, which may be properly recognized and enforced by such tribunals. It is a mere matter of his own good will and pleasure; and if he happens to hold a private domain within another territory, it may be that he cannot obtain full redress for any injury to it, except through the instrumentality of its Courts of justice. It may therefore be justly laid down as a general proposition, that all persons and property within the territorial jurisdiction of a sovereign, are amenable to the jurisdiction of himself or his Courts: and that the exceptions to this rule are such only as by common usage, and public policy, have been allowed, in order to preserve the peace and harmony of nations, and to regulate their intercourse in a manner best suited to their dignity and rights. ${ }^{72}$

Unlike the discussion of the public versus private distinction in The Schooner Exchange, which was arguably dicta, the discussion of the distinction in this case was part of its holding, as the Supreme Court allowed the District Court to maintain its jurisdiction over the disputed prize cargo in spite of Mr. Chaytor's and United Provinces' objections. ${ }^{73}$ Thus, in 1822, the Supreme Court held that if a foreign sovereign "comes personally within our limits" on business other than that which is regarded in customary international law as the public business of the foreign sovereign, the foreign sovereign and its property may be amenable to the process and jurisdiction of our courts. ${ }^{74}$ This holding again affirmed a view of sovereign immunity that is attuned to the restrictive theory.

71. Id. at 353 .

72. Id. at 353-54.

73. Id. at 354-55.

74. Id. at 353 . 


\section{The Planters' Bank Case}

In 1824, Chief Justice John Marshall had the opportunity to restate several of the principles from The Schooner Exchange and The Santissima Trinidad. This opportunity arose in the context of a challenge to the sovereign immunity of the State of Georgia in a case involving a partially state-owned corporation, the Planters' Bank of Georgia. ${ }^{75}$ The owners and incorporators of the Planters' Bank, one of whom was the State of Georgia, argued that claims concerning certain promissory notes undertaken by the bank could not be adjudicated in court because it would compel the appearance of a sovereign state. ${ }^{76}$ In rejecting the claim, Chief Justice Marshall stated:

It is, we think, a sound principle, that when a government becomes a partner in any trading company, it devests itself, so far as concerns the transactions of that company, of its sovereign character, and takes that of a private citizen. Instead of communicating to the company its privileges and its prerogatives, it descends to a level with those with whom it associates itself, and takes the character which belongs to its associates, and to the business which is to be transacted. . . . The State of Georgia, by giving to the Bank the capacity to sue and be sued, voluntarily strips itself of its sovereign character, so far as respects the transactions of the Bank, and waives all the privileges of that character. As a member of a corporation, a government never exercises its sovereignty. . . .

The government, by becoming a corporator, lays down its sovereignty, so far as respects the transactions of the corporation, and exercises no power or privilege which is not derived from the charter. ${ }^{77}$

The legal separateness of a sovereign-owned entity was upheld, along with the principle that a sovereign-owned entity that engages in private, commercial conduct-where the sovereign steps down from its throne to engage in trade like any other private person-will be subject to the civil enforcement of its contracts and obligations. ${ }^{78}$

These three cases of the 1820s, The Schooner Exchange, The Santissima Trinidad, and Planters' Bank, present a very modern view of sovereign immunity. Public actions of a sovereign acting in its capacity as a sovereign will enjoy the privilege of exemption from the process and jurisdiction of suits that is afforded in customary international law, up to the point where the territorial sovereign announces

75. Bank of the United States v. Planters' Bank of Ga., 22 U.S. (9 Wheat.) 904 (1824).

76. Id. at 904-05.

77. Id. at 907-08.

78. Id. 
that the privilege is revoked. ${ }^{79}$ A sovereign will not be compelled to appear as a defendant in the courts of a territorial sovereign so long as the sovereign confines its private activities to its own territory. ${ }^{80}$ Once it extends its private, commercial activities into the territory of another sovereign, it becomes subject to the judicial power of the other sovereign to compel it to answer for its private activities. ${ }^{81}$ And sovereign-owned entities that engage in private, commercial conduct will be required to answer for the conduct in civil proceedings just like any other merchant or private person. ${ }^{82}$

\section{E. Sovereign Immunity Before and After the Pesaro Decisions}

The retroactivity argument set forth most recently in Hwang Geum Joo v. Japan ${ }^{83}$ requires a finding that a foreign sovereign would have enjoyed a settled expectation of absolute immunity in the World War II era amounting to an antecedent right that should not be removed by legislation in the form of the FSIA. The argument is unsupported by the cases leading up to and during World War II. These cases establish that, except for a brief period between 1926 and 1938, United States courts followed the recommendations of the U.S. State Department and granted immunity to countries on good relations with the United States and, generally speaking, for public business of the foreign sovereign. As will be seen, the State Department espoused the restrictive theory of sovereign immunity as early as $1921 .^{84}$

During the brief period from 1926 to 1938 , the Supreme Court ordained that the United States followed the absolute theory of sovereign immunity without regard to the position taken by the State Department. ${ }^{85}$ World War II and most of the events of the Holocaust occurred after this hiatus. During the war, the Supreme Court rein-

79. Id. at 907-08; The Santissima Trinidad, 20 U.S. (7 Wheat.) 283, 353-55 (1822); The Schooner Exchange v. McFaddon, 11 U.S. (7 Cranch) 116, 141-43, $145-46$ (1812).

80. Planters' Bank, 22 U.S. (9 Wheat.) at 907-08; The Santissima Trinidad, 20 U.S. (7 Wheat.) at 353-55; The Schooner Exchange, 11 U.S. (7 Cranch) at 141-43, 145-46.

81. Planters' Bank, 22 U.S. (9 Wheat.) at 907-08; The Santissima Trinidad, 20 U.S. (7 Wheat.) at 353-55; The Schooner Exchange, 11 U.S. (7 Cranch) at 141-43, 145-46.

82. Planters' Bank, 22 U.S. (9 Wheat.) at 907-08; The Santissima Trinidad, 20 U.S. (7 Wheat.) at 353-55; The Schooner Exchange, 11 U.S. (7 Cranch) at 141-43, $145-46$.

83. 332 F.3d 679 (D.C. Cir. 2003). See also Mortara, supra note 17.

84. The Pesaro, 277 F. 473, 479 n.3 (S.D.N.Y. 1921) (Pesaro II).

85. See Berizzi Bros. Co. v. S.S. Pesaro, 271 U.S. 562 (1926) (Pesaro III). 
forced the State Department's role in granting immunity to public ships of friendly foreign nations. ${ }^{86}$

In the period following the trilogy of The Schooner Exchange, The Santissima Trinidad, and Planters' Bank, courts continued to hold that actions involving vessels employed in the public service of a foreign sovereign were not amenable to suit, but the sovereign could voluntarily participate in litigation without affecting the courts' jurisdiction. ${ }^{87}$ Few opinions addressed the concept that property of a foreign sovereign used or employed for private purposes would not be immune from the jurisdiction of the courts where the property may be found. In 1841, the court in Clarke v. New Jersey Steam Navigation Company went so far as to opine, in dicta, that property of a sovereign involved in private activities would be subject to the court's jurisdiction. ${ }^{88}$ In The Pizzaro v. Matthias, the Southern District of New York, although finding persuasive arguments in favor of an extension of The Santissima Trinidad to allow a pre-judgment attachment of a foreign public warship in a tort case arising from the allegedly negligent actions of the ship and her crew in American waters, ultimately declined to make the extension. ${ }^{89}$

The court in Long $v$. The Tampico ${ }^{90}$ was not so humble. Although reaffirming the general principle that no suit in rem in admiralty can be sustained, or seizure made by the marshal, under process against property of a foreign government devoted to public uses and in possession of an officer of the foreign government, ${ }^{91}$ the court drew a fine distinction allowing an in rem claim when the property had not yet been delivered into the possession of an officer of the foreign government. ${ }^{92}$ Thus, although the property interest and public purpose of

86. See Republic of Mexico v. Hoffman, 324 U.S. 30 (1945); Ex parte Peru, 318 U.S. 578 (1943).

87. See e.g., The Sapphire, 78 U.S. (11 Wall.) 164, 167-68 (1870); Colombia v. Cauca Co., 190 U.S. 524, 525-26 (1903).

88. 5 F. Cas. 974, 977 (C.C.D.R.I. 1841) (No. 2,859).

89. 19 F. Cas. 786, 788-90 (S.D.N.Y. 1852) (No. 11,199). The court declined to make the extension upon deciding that it was bound by the limited holdings of The Schooner Exchange and The Santissima Trinidad as to public warships. Id. The case involved a collision near Staten Island between the steamship Pizzaro, owned and operated as a warship of Italy, and the schooner Thomas Conner owned by the libellant. The court considered whether an attachment of the Italian public vessel to secure judgment might be appropriate in cases where the claimant seeks damages in tort caused by the instrumentality of the foreign government acting within the territorial jurisdiction of the United States. Id. at 786-89.

90. 16 F. 491 (S.D.N.Y. 1883).

91. Id. at 496.

92. Id. at 501 . 
the Mexican government in the vessels was not questioned, ${ }^{93}$ the location and control of the actual vessels was deemed to be of great importance. ${ }^{94}$ The court in The Attualita extended this rule and held that a suit in rem against a vessel for damages caused by the vessel in a collision on the high seas could be sustained even though the court was informed during the pendency of the suit that the vessel had been requisitioned for public use of the Italian government in World War I. ${ }^{95}$ The court noted that the ship had not yet passed into the possession and public service of the Italian government, and rejected the contention of the lower court in the case that attachment of the ship would tend "to disturb the international comity existing between the two nations, which are now friendly." 96

The same result is found in The Johnson Lighterage Co. No. 24, which upheld in rem claims for salvage services against property of the Russian government that was destined for public use, in that the property was not in the actual possession of an officer of the Russian government. ${ }^{97}$ The court based its decision on an interpretation of the law that a territorial sovereign could not be deemed to have waived the jurisdiction of its courts with regard to foreign sovereigns in situations where such waiver is not afforded to the territorial sovereign itself. ${ }^{98}$ The court believed that property of United States would be subject to attachment in these circumstances:

In the absence of treaty provisions, I know of no principle which, in a case such as this, would afford a foreign government greater immunity from judicial process than that which is enjoyed by our own government. The immunity granted to friendly foreign governments rests upon international comity; but the underlying principle upon which the immunity is granted is, nevertheless, the same in both cases, namely, that the exercise of jurisdiction is inconsistent with the independence of sovereign authority and public policy. ${ }^{99}$

93. The vessels were destined to be revenue cutters of the foreign sovereign, Mexico. Id. at 492.

94. Id. at 501 .

95. 238 F. 909, 911 (4th Cir. 1916).

96. Id. at 911-12,913. Note that in 1916, the United States had not entered World War I and was not a co-belligerent of the Italian government. The State Department had informed the court that the ship had been requisitioned by the Italian government, but the court construed the communication to mean that the executive branch took no position and made no formal suggestion as to proper action of the court with regard to the issues of sovereign immunity in the case. See id. at 911.

97. 231 F. 365,368 (D.N.J. 1916).

98. Id.

99. Id. (citations omitted). 
The cases involving the United States as sovereign to which the Johnson Lighterage court referred largely paralleled those involving foreign sovereigns. Justice Story, sitting as Circuit Judge for the Circuit Court for the District of Massachusetts, held in United States $v$. Wilder that a lien for general average may be enforced against the property of the sovereign that was not public property employed for a particular public purpose. ${ }^{100}$ In that case, the United States had appeared voluntarily in the action to assert its claim to the property at issue. The court in The Siren applied the same reasoning to allow a set off in rem asserted under a salvage lien against a ship claimed as prize by the United States. ${ }^{101}$ Once again, the sovereign had initiated the litigation by asserting a prize claim over the vessel. This opinion was extended by The Davis, which held that jurisdiction obtained by an attachment in rem to enforce a salvage claim against the property of the United States could be sustained even though it potentially would hale the sovereign into court against its will to defend its claim to the property, so long as the attachment of the property did not involve interference with any officer or agent of the sovereign. ${ }^{102} \mathrm{Al}$ though the United States undeniably had a claim to the property, the property was arrested by the marshal of the district prior to its delivery to the United States. ${ }^{103}$ Although persuasive in their reasoning and in their numbers, these cases do not reflect a uniform trend in the nineteenth and early twentieth centuries. ${ }^{104}$

The 1921-26 federal cases arising from the collision of the Italian steamship Pesaro mark another watershed in the United States law of sovereign immunity. ${ }^{105}$ The Pesaro was a merchant steamship owned and operated by the Italian government, engaged in trade and the carriage of persons. ${ }^{106}$ At first, the Supreme Court, Justice Van Devanter, affirmed the principles that had been laid down a few weeks

100. 28 F. Cas. 601,604 (C.C.D. Mass. 1838) (No. 16,694).

101. 74 U.S. (7 Wall.) 152, 157-59 (1868).

102. 77 U.S. (10 Wall.) 15, 19-22 (1869).

103. Id. at 22.

104. See, e.g., Briggs v. Light-Boat Upper Cedar Point, 93 Mass. (11 Allen) 157 (1865) (light boats owned by United States and operated for public purposes were not subject to workmen's and materialmen's liens enforced in rem against property of sovereign); The Fidelity, 8 F. Cas. 1189 (C.C.S.D.N.Y. 1879) (No. 4,758) (steam tug owned by municipal corporation not liable to suit in rem in admiralty brought to recover damages for act committed while engaged in public service); Ex parte New York, No. 2, 256 U.S. 503 (1921) (same; vessel owned by sovereign State of New York).

105. See generally The Pesaro, 255 U.S. 216 (1921) (Pesaro I), remanded, 277 F. 473 (S.D.N.Y. 1921) (Pesaro II), rev'd sub nom Berizzi Bros. Co. v. S.S. Pesaro, 271 U.S. 562 (1926) (Pesaro III).

106. Pesaro II, $277 \mathrm{~F}$. at $473-74$. 
before in Ex parte Muir (also written by Justice Van Devanter), ${ }^{107}$ holding that a claim of immunity made directly by the ambassador of a foreign nation will not be acknowledged by the court until and unless the sovereign or its authorized representative makes a formal appearance in the suit as a party or proceeds through proper diplomatic channels to cause the suggestion of immunity to come to the court from the executive branch. ${ }^{108}$ Thus, the case was remanded to the district court for further proceedings.

The case on remand was considered by Circuit Judge Mack, who proceeded to write an exemplary dissertation on the restrictive view of sovereign immunity. ${ }^{109}$ Judge Mack reviewed the domestic case law and surveyed as many European authorities as he could find to make his determination that customary international law did not afford immunity to a sovereign owned vessel that is carrying out private, commercial services for the sovereign. ${ }^{110}$ Judge Mack was bolstered in his decision by the fact that the State Department, upon the court's request, had issued the following communication to the court:

It is the view of the Department that government-owned merchant vessels or vessels under requisition of governments whose flag they fly employed in commerce should not be regarded as entitled to the immunities accorded public vessels of war. The Department has not claimed immunity for American vessels of this character. In cases of private litigation in American ports involving merchant vessels owned by foreign governments, the Department has made it a practice carefully to refrain from taking any action which might constitute an interference by the authorities of this government in such litigation. ${ }^{111}$

This communication from the State Department indicates its adoption of the view that merchant ships owned and operated by a foreign government are not entitled to sovereign immunity. The Supreme Court, again by Justice Van Devanter, simply rejected the reasoning of Judge Mack's opinion and the recommendation of the State Department and declared that the United States follows the absolute theory of sovereign immunity. ${ }^{112}$ The Court held that immunity from

107. 254 U.S. 522 (1921). Ex parte Muir involved a claim of immunity asserted by private counsel of the British government, appearing only as amici curiae in the suit, not through entry of appearance as a suitor nor by diplomatic communication of the claim through the State Department. The court refused to issue an extraordinary writ to quash the jurisdiction of the lower court on the basis of this claim. Id. at 532-34.

108. Pesaro I, 255 U.S. at 218-19.

109. See generally Pesaro II, 277 F. 473.

110. Id.

111. Id. at 479 n.3.

112. Berizzi Bros. Co. v. S.S. Pesaro, 271 U.S. 562, 571-74 (1926) (Pesaro III). 
the jurisdiction of the courts was owed to a sovereign owned merchant vessel engaged in commercial activities. ${ }^{113}$ The Court held, further, that it was inappropriate to assume that customary international law required that trade and commerce necessarily were private activities of a sovereign, and concluded that trade and commerce certainly might be regarded as essential for the economic welfare of the nation, and thus public in nature. ${ }^{114}$ A vessel carrying out trade and commerce for the benefit of the nation was as much carrying out the public purposes of the state as a ship of war, and should be afforded the same immunities. ${ }^{115}$

The Pesaro III opinion did not end the debate. Although the distinction of public and private property was put on the back burner by the Supreme Court, the lower courts shifted focus back to the executive's recommendations as to sovereign immunity. ${ }^{116}$ But for a relatively brief period starting in 1926 and ending by 1938 at the latest with the decision in Compania Espanola de Navegacion Maritima $v$. The Navemar, ${ }^{117}$ the Supreme Court of the United States, contrary to the stated position of the State Department, had ordained that the United States followed the absolute theory of sovereign immunity.

\section{F. The Courts' Reaction to Executive Communications on Matters of Sovereign Immunity after Pesaro III and Before 1952}

Pesaro III was an aberration in a fairly consistent process of courts following recommendations of the executive branch regarding the immunities granted to foreign sovereigns. In fact, the courts' reliance on the suggestions of the State Department regarding the sovereign status of the defendant and the public or sovereign nature of the activities from which the litigation arose was one of the most notable developments in sovereign immunity law of the mid-nineteenth to early twentieth century. ${ }^{118}$ By the early twentieth century, with the exception of the Pesaro III decision, it had become clear that United

113. Id. at 574,576 .

114. Id. at 574 .

115. Id.

116. See, e.g., United States v. Deutsches Kalisyndikat Gesellschaft, 31 F.2d 199, 200 (S.D.N.Y. 1929).

117. 303 U.S. 68, 74 (1938).

118. See Hassard v. Mexico, 61 N.Y.S. 939 (App. Div. 1899), aff'd, 66 N.E. 1110 (N.Y. 1903) (noting that U.S. Attorney had intervened in suit to assert immunity of Mexico, and following his recommendation); Molina v. Comision Reguladora del Mercado de Henequen, 103 A. 397 (N.J. 1918) (holding silence of State Department to be important to court's decision to deny claim of immunity to corporation owned by Mexican Yucatan state). But cf. United States v. Wong Kim Ark, 169 U.S. 649 (1898) (declaring that Fourteenth Amendment to United States Constitution gave citi- 
States courts would rely on the suggestion of the executive branch regarding the jurisdictional immunity owed to a foreign sovereign or its property. ${ }^{119}$ It was also clear that in the absence of such suggestion, by inaction or by refusal, the courts would exercise jurisdiction to resolve the issues of the case, leaving the foreign sovereign with the sole option of joining the suit as a party in order to prove its claims of sovereignty and immunity. ${ }^{120}$

The Supreme Court, per Justice Stone in The Navemar, tipped the scales in favor of judicial recognition of the recommendations of the State Department when it stated:

If the claim is recognized and allowed by the executive branch of the government, it is then the duty of the courts to release the vessel upon appropriate suggestion by the Attorney General of the United States, or other officer acting under his direction. ${ }^{121}$

This statement was dictum, as the State Department had refused to state any position on the immunities to be afforded Spain in the case, although the Spanish Ambassador had attempted to assert the claims through an informal communication to the court, and later by moving the Court to intervene in the suit. ${ }^{122}$ The Supreme Court went on to approve American courts' continuance of jurisdiction over the case until the issue of sovereign immunity could properly be determined:

The Department of State having declined to act, the want of admiralty jurisdiction because of the alleged public status of the vessel and the right of the Spanish Government to demand possession of the vessel as owner if it so elected, were appropriate subjects for judicial inquiry upon proof of the matters alleged.

But the filed suggestion [of the Spanish Ambassador], though sufficient as a statement of the contentions made, was not proof of its allegations. This Court has explicitly declined to give such a suggestion the force of proof or the status of a like suggestion coming from the executive department of our government. ${ }^{123}$

zenship to U.S.-born children of foreign nationals in spite of executive and legislative position on their status under Chinese Exclusion Acts).

119. Ex parte Peru, 318 U.S. 578, 588 (1943); The Navemar, 303 U.S. 68, 74 (1938); The Gul Djemal, 264 U.S. 90 (1924); Ex parte Hussein Lutfi Bey, 256 U.S. 616, 619 (1921); Ex parte Muir, 254 U.S. 522, 523-33 (1921).

120. See Ex parte Peru, 318 U.S. at 588; The Navemar, 303 U.S. at 74; The Gul Djemal, 264 U.S. at 94; Ex parte Hussein Lutfi Bey, 256 U.S. at 619; Ex parte Muir, 254 U.S. at 532-33.

121. 303 U.S. at 74.

122. Id. at 70-71.

123. Id. at 75 . 
The Court then remanded the case to allow the Spanish government to intervene in the suit as a claimant, following the rule laid down in Ex parte Muir and Pesaro I. ${ }^{124}$ The Court thus gave notice that it was continuing the policy of requiring foreign states to pursue their claims of immunity through the State Department (which might refuse to support the claim of immunity) or by direct intervention in the suit as a claimant.

Although after The Navemar the courts tended to follow direct recommendations of the executive branch communicated to the courts through the Attorney General or the local United States Attorney, ${ }^{125}$ the nature of recommendations of the executive branch regarding immunities to be extended to foreign governments and the courts' reaction to these suggestions were far from uniform. ${ }^{126}$ The Second Circuit in particular, with its large docket of admiralty cases, had several occasions to rule on this issue after Pesaro III and The Navemar, and apparently, it construed these two opinions to mean that courts were free to make up their own minds as to immunity in particular cases. ${ }^{127}$

In his three opinions in The Navemar, Ex parte Peru, and Mexico v. Hoffman, ${ }^{128}$ Chief Justice Harlan Fiske Stone steered the federal courts into the position that sovereign immunity was to be evaluated with deference to the suggestions of the political branches of the government, ${ }^{129}$ and in the absence of a recommendation by the political

124. Id. at 76 (citing Ex parte Muir, 254 U.S. 522 (1921); Pesaro I, 255 U.S. 216, $219(1921))$.

125. E.g., Ex parte Peru, 318 U.S. at 588-89.

126. Compare Miller v. Ferrocarrill del Pacifico de Nicaragua, 18 A.2d 688 (Me. 1941) (finding that executive's mere communication of claim of foreign government without comment is tacit indication of approval of claim, and granting immunity), with The Attualita, 238 F. 909 (4th Cir. 1916) (finding that mere communication of immunity of Italy without stating position on the claim is not tacit approval, and refusing claim of immunity), accord Lamont v. Travelers Ins. Co., 24 N.E.2d 81 (N.Y. 1939), and Hannes v. Kingdom of Roumania Monopolies Institute, 20 N.Y.S.2d 825 (N.Y. App. Div. 1940).

127. Compare Puente v. Spanish Nat'l State, 116 F.2d 43 (2d Cir. 1940) (holding that court could take judicial notice of immune status of defendant in spite of executive silence on issue), with Sullivan v. São Paulo, 122 F.2d 355 (2d Cir. 1941) (finding that executive's communication was construed as approval of claim of immunity, but such executive position was not deemed to be conclusive of the issue), and Banco de Espana v. Fed. Reserve Bank of N.Y., 114 F.2d 438 (2d Cir. 1940) (same).

128. 324 U.S. 30 (1945).

129. The Navemar, 303 U.S. at 74 ("If the claim is recognized and allowed by the executive branch of the government, it is then the duty of the courts to release the vessel upon appropriate suggestion by the Attorney General. . .."); Ex parte Peru, 318 U.S. at 589 ("This practice is founded upon the policy ... that our national interest will be better served ... if the wrongs to suitors, involving our relations with a 
branch, as determined by the courts based on their own understanding of the United States' practice of sovereign immunity. ${ }^{130}$ The culmination of the process, as stated in Hoffman, was the following interpretation of the law:

In the absence of recognition of the claimed immunity by the political branch of the government, the courts may decide for themselves whether all the requisites of immunity exist. That is to say, it is for them to decide whether the vessel when seized was that of a foreign government and was of a character and operated under conditions entitling it to the immunity in conformity to the principles accepted by the department of the government charged with the conduct of our foreign relations. ${ }^{131}$

Chief Justice Stone's policy was to defer to the political branches, particularly the executive branch, as it is charged with the conduct of international relations, and to avoid "embarrassment" of the executive branch either by granting jurisdiction over foreign sovereigns where the executive has chosen to waive it, or by denying jurisdiction over foreign sovereigns in circumstances where the executive branch would like to send a message by refusing to waive jurisdiction. ${ }^{132}$

Chief Justice Stone did not tie up the issue of sovereign immunity as a nonjusticiable political question akin to the act of state doctrine. He set it down as an issue of deferring to the executive branch of government when its position is clear, and determining what the proper position of the government should be when the executive branch is silent. He thus quietly overruled Pesaro III, which had ignored the stated position of the executive branch on immunities to be given to state-owned vehicles that were operated for commercial purposes. ${ }^{133}$ This fact is driven home by the holding of the case: that a steamship owned by the government of Mexico but possessed and operated under a charter by private parties engaged in trade and commerce was not entitled to sovereign immunity protection. ${ }^{134}$

friendly foreign power, are righted through diplomatic negotiations rather than by the compulsions of judicial proceedings.").

130. The Navemar, 303 U.S. at 75 ("The Department of State having declined to act, the want of ... jurisdiction because of the alleged public status of the vessel ... [was an] appropriate subject[ ] for judicial inquiry upon proof of the matters alleged.").

131. Hoffman, 324 U.S. at 34-35 (citations omitted).

132. Id. at $35-36$.

133. Id. at $35 \mathrm{n} .1$. The overruling of the case was so quiet and respectful that Justice Frankfurter felt compelled to highlight with approval the Court's retreat from the principles of Pesaro III in his concurring opinion, joined by Justice Black. Id. at 39 (Frankfurter, J., concurring).

134. Id. at 33,38 . 
Such was the nature of the political process, that changing diplomatic relationships and changing political administrations often led to various and, at times, inconsistent outcomes. However, this variety of results, although not entirely predictable, was consistent with United States courts' overall interpretation of sovereign immunity, because sovereign immunity had historically been justified by political considerations in international relations, and not as a recognition of the rights of foreign sovereigns. ${ }^{135}$ Thus, politics and international policy would call for the extension of comity and grace in the form of the recognition of sovereign immunity in certain situations, but not in others. If anything was made known to the community of nations by the courts of the United States "in a manner not to be misunderstood,"136 it was this fact.

\section{G. State Department Communications on Sovereign Immunity Regarding State-Sponsored Plunder and Other "Private" Acts}

The State Department's policy regarding immunity for private acts followed a fairly consistent path in the twentieth century. As noted in Pesaro II, as of 1921, the State Department accepted the fundamentals of the restrictive theory of sovereign immunity. ${ }^{137}$

In cases where it appeared that a vessel was possessed and operated by a foreign government directly, and where extension of the immunity would serve its ends, the State Department tended to make a direct suggestion of immunity. ${ }^{138}$ In cases where the circumstances did not indicate that the foreign sovereign directly possessed and operated a vessel, or where extension of immunity would not serve its purposes, the State Department tended not to take a position in the matter. ${ }^{139}$ This was also true in cases where the foreign sovereign was

135. See, e.g., Ex parte Peru, 318 U.S. 578, 589 (1943); Berizzi Bros. v. The Pesaro, 271 U.S. 526, 571-73 (1926) (Pesaro III); The Santissima Trinidad, 20 U.S. (7 Wheat.) 283, 353 (1822); The Schooner Exchange, 11 U.S. (7 Cranch) 116, 146 (1812).

136. The Schooner Exchange, 11 U.S. (7 Cranch) at 146.

137. See supra note 111 and accompanying text (quoting letter from Secretary of State to court in The Pesaro, 277 F.473, 479 n.3 (S.D.N.Y. 1921) (Pesaro II)).

138. E.g., Ex parte Peru, 318 U.S. 578 (1943).

139. E.g., The Navemar, 303 U.S. 68 (1938); Mexico v. Hoffman, 324 U.S. 30,30 (1945). 
not considered to be "friendly," 140 or in situations where the U.S. government had broken off relations with the foreign sovereign. ${ }^{141}$

Of particular importance to the issues of retroactivity with regard to claims arising out of the Nazi plunder of Europe during World War II, in January 1943, the United States and seventeen of its allies issued the "Declaration Regarding Forced Transfers of Property in EnemyControlled Territory," 142 warning of their intent "to do their utmost to defeat the methods of dispossession practiced by the governments with which they are at war against the countries and peoples who have been so wantonly assaulted and despoiled." ${ }^{143}$ The declaration continued:

Accordingly the governments making this declaration and the French National Committee reserve all their rights to declare invalid any transfers of, or dealings with, property, rights and interests of any description whatsoever which are, or have been, situated in the territories which have come under the occupation or control, direct or indirect, of the governments with which they are at war or which belong or have belonged, to persons ... resident in such territories. This warning applies whether such transfers or dealings have taken the form of open looting or plunder, or of transactions apparently legal in form, even when they purport to be voluntarily effected. ${ }^{144}$

Six years later, the State Department again announced its position that the courts should proceed with claims for repossession of Nazi

140. On many occasions, the State Department's silence might be explained by the unfriendly or "neutral" relations between the United States and the foreign power. See, e.g., The Navemar, 303 U.S. 68 (concerning claim made by Spain during Spanish Civil War between Loyalist forces and fascist Nationalist forces under Franco, and United States' adoption of position of neutrality during conflict).

141. Ex parte Hussein Lutfi Bey, 256 U.S. 616, 619 (1921); The Gul Djemal, 264 U.S. 90, 91-94 (1924). These cases involved the extension of immunity to the Ottoman Empire in Turkey with whom the United States had broken off relations during the time period relevant to the actions. The Gul Djemal, 264 U.S. at 91. The U.S. State Department refused to offer a suggestion in support of immunity, and Turkey had attempted to assert a defense of immunity through the appearance of the captain of the vessel, Mr. Hussein Lufti Bey. Id. The Supreme Court, although recognizing that the vessel was owned and operated by the Turkish Government, and noting that Turkey, at the time of suit, was not hostile to the United States, nevertheless on two occasions refused to entertain the claim to immunity through the petition of the captain of the ship, and permitted the lower court to entertain jurisdiction over the suit in the absence of a properly asserted suggestion of immunity. Id. at 94-95.

142. Dep't St. Bull., Jan. 9, 1943, at 21-22.

143. Id. at 21 .

144. Id. at 21-22. 
plundered property in a press release published on April 27, 1949. ${ }^{145}$ The State Department press release stated, in pertinent part:

As a matter of general interest, the Department publishes herewith a copy of a letter of April 13, 1949 from Jack B. Tate, Acting Legal Advisor, Department of State, to the Attorneys for the plaintiff in Civil Action No. 31-555 in the United States District Court for the Southern District of New York.

The letter repeats this Government's opposition to forcible acts of dispossession of a discriminatory and confiscatory nature practiced by the Germans on the countries or peoples subject to their controls; states that it is this Government's policy to undo the forced transfers and restitute identifiable property to the victims of Nazi persecution wrongfully deprived of such property; and sets forth that the policy of the Executive, with respect to claims asserted in the United States for restitution of such property, is to relieve American courts from any restraint upon the exercise of their jurisdiction to pass upon the validity of the acts of Nazi officials. ${ }^{146}$

The letter from Mr. Tate is then quoted in pertinent part:

1. This Government has consistently opposed the forcible acts of dispossession of a discriminatory and confiscatory nature practiced by the Germans on the countries or people subject to their controls.

3. The policy of the Executive, with respect to claims asserted in the United States for the restitution of identifiable property (or compensation in lieu thereof) lost through force, coercion, or duress as a result of Nazi persecution in Germany, is to relieve American courts from any restraint upon the exercise of their jurisdiction to pass upon the validity of the acts of Nazi officials. ${ }^{147}$

The post-war situation with Japan was different. As pointed out by the D.C. Circuit in Joo v. Japan, the 1951 Treaty of Peace between Japan and the Allied powers explicitly waived "all . . claims of the Allied Powers and their nationals arising out of any actions taken by Japan and its nationals in the course of the prosecution of the war" in return for a reciprocal waiver of claims by Japan and the right of the Allied Powers to seize Japanese assets within the Allies' respective

145. Press Release No. 296, Jurisdiction of United States Courts Re Suits for Identifiable Property Involved in Nazi Forced Transfers, State Dep't (Apr. 27, 1949), reprinted in Bernstein v. N.V. Nederlandsche-Amerikaansche, 210 F.2d 375, 375-76 (2d Cir. 1954) [hereinafter Press Release No. 296]; see also Altmann v. Republic of Austria, 317 F.3d 954, 965-66 (9th Cir. 2002) (Altmann II).

146. Bernstein, 210 F.2d at 376 (quoting Press Release No. 296, supra note 145).

147. Letter from Jack B. Tate, Acting Legal Advisor, Department of State, to Attorneys for plaintiff in Civil Action No. 31-555 in the United States District Court for the Southern District of New York (Apr. 13, 1949), quoted in Bernstein, 210 F.2d at 376; see also Altmann II, 317 F.3d at 965-66. 
jurisdictions. ${ }^{148}$ The Treaty further provided that Japan would also resolve any war-related claims of other United Nations member states and their nationals through intergovernmental agreements. ${ }^{149}$ Japan entered such agreements with China and Korea, but not with Germany or Austria. ${ }^{150}$

The State Department followed the 1949 Tate communication with the more famous Tate Letter of 1952, which reaffirmed that the United States had joined the sizeable list of nations that followed the restrictive view of sovereign immunity. ${ }^{151}$

From 1952 to 1976, the State Department's pronouncements continued to influence the immunities granted to sovereign states. ${ }^{152}$ At times, the Department made recommendations that appeared to be politically and foreign policy motivated, subject to the diplomatic pressures and influences of foreign states rather than by a strict adherence to the restrictive theory of sovereign immunity. ${ }^{153}$ This became a motivating factor for the codification and standardization of the restrictive theory and for transferring the determination process from the executive branch to the courts through legislation that became the FSIA.

148. Joo v. Japan, 332 F.3d 679, 685 (D.C. Cir. 2003) (quoting Multilateral Treaty of Peace with Japan, Sept. 8, 1951, art. 14, 3 U.S.T. 3169, 3183).

149. Multilateral Treaty of Peace with Japan, supra note 148, art. 26, 3 U.S.T. at $3190 ; J o o, 332$ F.2d at 685.

150. Joo, 332 F.2d at 685 (citing Treaty of Peace Between the Republic of China and Japan, Apr. 28, 1952, 138 U.N.T.S. 3; Agreement on the Settlement of Problems Concerning Property and Claims on the Economic Co-operation Between Japan and the Republic of Korea, June 22, 1965, 583 U.N.T.S. 173). Although the D.C. Circuit's primary holding in Joo is that the FSIA is not a jurisdictional statute and is not intended by Congress to operate retroactively beyond 1952, the case alternatively holds that if the analysis in Altmann II (that the FSIA should apply to the conduct of Nazi Germany and Austria in World War II because the State Department had given clear indications that Germany and its affiliates would not enjoy protection from prosecution) is correct, then the situation with Japan is different. Id. at 684-85.

151. Tate Letter of 1952, supra note 14.

152. E.g., Nat'l City Bank of N.Y. v. Republic of China, 348 U.S. 356 (1955); Alfred Dunhill of London, Inc. v. Republic of Cuba, 425 U.S. 682, 696-97 \& app. 1 at 706-11 (1976).

153. E.g., Isbrandtsen Tankers, Inc. v. President of India, 446 F.2d 1198, 1199 (2d Cir. 1971); Rich v. Naviera Vacuba, S.A., 197 F. Supp. 710 (E.D. Va.), aff'd, 295 F.2d 24 (4th Cir. 1961); see Jurisdiction of U.S. Courts in Suits Against Foreign States: Hearing on H.R. 11315 Before the Subcomm. on Admin. Law and Governmental Relations of the House Comm. on the Judiciary, 94th Cong. 34-35 (1976) (testimony of Monroe Leigh, Legal Adviser, Department of State); Monroe Leigh, Sovereign Immunity-The Case of the "Imias," 68 AM. J. INT'L L. 280 (1974). 


\section{H. Interpretation and Implementation of the Principles of Sovereign Immunity After 1952}

Decisions after the Tate Letter are important because they point out two facts that are important to the retroactivity argument: first, recommendations of the State Department always were made according to the state of relations at the time of suit, not necessarily at the time of events from which the suit arose. Second, the application of jurisdiction over events that happened earlier has never been questioned by the courts as a potentially improper retroactive denial of antecedent rights. The most likely explanation for this is that sovereign immunity has never been regarded as a "right" of foreign states. It has always been explained as a matter of grace and comity, which can be withdrawn simply by giving notice.

\section{The Limited Doctrine of Immunity: The Distinction Between}

Public and Private Actions

The Supreme Court was quick to follow up on the executive's restatement of policy to follow the restrictive view of sovereign immunity. In 1955, the Court held that an action to enforce a pledge of security by the Republic of China in 1920 and a separate pledge made in 1947-48, arising from events that occurred well before the 1952 Tate Letter, was properly adjudicated by the federal courts. ${ }^{154}$ The Court specifically noted the State Department's adherence to the restrictive view of sovereign immunity that was reaffirmed in the Tate Letter, but had no qualms about applying this theory to conduct that predated the Tate Letter. ${ }^{155}$

The Tate Letter failed to lay out specific criteria for public acts of a sovereign nation that would enjoy immunity from jurisdiction as opposed to private acts that would not. The Schooner Exchange, The Santissima Trinidad and Planters' Bank trilogy of cases had suggested the metaphors that "if a sovereign descend from the throne and become a merchant,"156 "lay[s] down the prince, and assum[es] the character of a private individual," 157 or "comes personally within our limits" 158 he would be subject to the territorial jurisdiction of the

154. Nat'l City Bank of N.Y., 348 U.S. at 360-65.

155. Id. at 361 .

156. The Schooner Exchange v. McFaddon, 11 U.S. (7 Cranch) 116, 123 (1812); see also Alfred Dunhill of London, Inc., 425 U.S. at 696; Ohio v. Helvering, 292 U.S. 360,369 (1934); Bank of the U.S. v. Planters' Bank of Ga., 22 U.S. (9 Wheat.) 904, 907 (1824).

157. The Schooner Exchange, 11 U.S. (7 Cranch) at 145.

158. The Santissima Trinidad, 20 U.S. (7 Wheat.) 283, 353 (1822). 
courts. But defining acts of sovereignty versus acts of a private citizen carried on by a sovereign-even in cases involving sovereign-owned merchant ships-proved to be troublesome. ${ }^{159}$ The Second Circuit filled the gap in Victory Transport, Inc. v. Comisaria General de Abastecimientos $y$ Transportes, ${ }^{160}$ which set forth the following criteria for public sovereign acts that would be immune from jurisdiction: (1) internal administrative acts, such as expulsion of an alien; (2) legislative acts, such as nationalization; (3) acts concerning the armed forces; (4) acts concerning diplomatic activity; and (5) public loans. ${ }^{161}$ These criteria were followed by other federal courts in the period before the enactment of the FSIA. ${ }^{162}$

The Court in Alfred Dunhill of London, Inc. v. Republic of Cuba, in a plurality opinion, applied the restrictive theory to allow claims to recover payments made for cigar shipments after the owners of the cigar producers had been replaced by "intervention" (expropriation) by the Castro regime in Cuba in 1960. ${ }^{163}$ The plurality opinion specifically relied on the Tate Letter, ${ }^{164}$ and pointed out that as of 1976, thirteen countries followed the restrictive theory-most notably England, France, and Germany. ${ }^{165}$

Most of the Supreme Court cases on sovereign immunity since the enactment of the FSIA have involved commercial transactions. In Verlinden B.V. v. Central Bank of Nigeria, a unanimous Court applied the restrictive theory embodied in the FSIA to a contract action by a Dutch corporation against the Central Bank of Nigeria for payment for

159. See P. de Paepe, De la compétence civile á l'égard des Etats étrangers et de leurs agents politiques, diplomatiques ou consulaires, 22 JOURNAL DU DROIT INTERNattonal Privé 31, 33 (1895); J.-F. Lalive, L'immunité de jurisdiction des États et des organisations internationales, 84 ReCUEIL DES Cours 205, 259-60 (1953); H. Lauterpacht, The Problem of Jurisdictional Immunities of Foreign States, 28 BRIT. Y.B. INT'L L. 220, 225 (1951); Preliminary Draft, Convention on the Competence of Courts in Regard to Foreign States, in RESEARCH IN INTERNATIONAL LAw: HARVARD LAW SCHOOL 311, 386-91 (1931); André Weiss, Compétence ou incompétence des tribunaux a l'égard des États étrangers, 1 ReCUEIL DEs Cours 525 (1923); see also, e.g., Ervin v. Quintanilla, 99 F.2d 935, 940-41 (5th Cir. 1938); The Gul Djemal, 264 U.S. 90, 94-95 (1924); Ex parte Hussein Lutfi Bey, 256 U.S. 616, 619 (1921).

160. 336 F.2d 354, 362-63 (2d Cir. 1964) (holding that Spain could be haled into court for engaging in private conduct in form of entry into shipping charter agreement with arbitration clause).

161. Id. at 360 (quoting Lalive, supra note 159 , at 285-86).

162. E.g., Spacil v. Crowe, 489 F.2d 614 (5th Cir. 1974); Heaney v. Spain, 445 F.2d 501, 503 (2d Cir. 1971); Isbrandtsen Tankers, Inc. v. President of India, 446 F.2d 1198, 1200 (2d Cir. 1971).

163. 425 U.S. 682, 705-06 (1976).

164. Id. at 698,711 .

165. Id. at 702 n.15. 
cement shipments. ${ }^{166}$ And the Court in Republic of Argentina $v$. Weltover, Inc., again in a unanimous opinion, held that issuance of currency stabilization bonds was a private, commercial act of the foreign sovereign that did not afford it immunity from a contract action to enforce the bonds. ${ }^{167}$

In contrast, the practices of a sovereign nation in running a stateowned hospital and recruiting workers and technicians in the United States to work in that hospital were held to be private acts that did not qualify for one of the exceptions to sovereign immunity under the FSIA. ${ }^{168}$ This holding was not disturbed by the fact that after recruiting respondent Nelson to work at the Saudi-owned hospital, agents of the government imprisoned and tortured him for making safety recommendations concerning equipment and practices at the hospital that were not well-received by the government. ${ }^{169}$

There is a line of federal cases involving the Cuban expropriation of American property after the communist takeover of Cuba under Castro in 1960.170 These cases, however, were decided under the act of state doctrine rather than the sovereign immunity jurisdictional doctrine, so they do not directly affect the issues regarding the proper application of sovereign immunity before and after the FSIA's enactment. The Supreme Court, following the Underhill doctrine ${ }^{171}$ and relying heavily on the State Department's intentional silence in the face of inquires concerning the foreign policy implications of the suit, initially declared that Cuba's seizure and expropriation of property in Cuba presented a nonjusticiable political question that could not be

166. 461 U.S. $480,488,497$ (1983).

167. 504 U.S. 607,620 (1992).

168. Saudi Arabia v. Nelson, 507 U.S. 349, 351 (1993).

169. Id. at 352-53.

170. Banco Nacional de Cuba v. Chem. Bank N.Y. Trust Co., 658 F.2d 903 (2d Cir. 1981); Banco Para el Comercio Exterior de Cuba v. First Nat'l City Bank, 658 F.2d 913 (2d Cir. 1981), rev'd, 462 U.S. 611 (1983); Banco Nacional de Cuba v. Chase Manhattan Bank, 658 F.2d 875 (2d Cir. 1981); Banco Nacional de Cuba v. First Nat'1 City Bank of N.Y., 270 F. Supp. 1004 (S.D.N.Y. 1967), rev'd, 43I F.2d 394 (2d Cir. 1970), vacated by 400 U.S. 1019 (1971); Banco Nacional de Cuba v. Sabbatino, 193 F. Supp. 375 (S.D.N.Y. 1961), aff'd, 307 F.2d 845 (2d Cir. 1962), rev'd, 376 U.S. 398 (1964).

171. See Underhill v. Hernandez, 168 U.S. 250 (1897). This case provided the classic statement of the act of state doctrine:

Every sovereign State is bound to respect the independence of every other sovereign State, and the courts of one country will not sit in judgment on the acts of the government of another done within its own territory. Redress of grievances by reason of such acts must be obtained through the means open to be availed of by sovereign powers as between themselves.

Id. at 252. 
reviewed by U.S. courts. ${ }^{172}$ Later, after passage of the Hickenlooper Amendment to the Foreign Assistance Act of $1964,{ }^{173}$ and even later, after the enactment of the FSIA and after the State Department had issued its opinion that nothing should hinder the courts from making determinations regarding the unlawful seizure of American property in Cuba, the courts allowed the determination of setoff claims and counterclaims against Cuban state-owned entities. ${ }^{174}$ It is significant to note, however, that the Supreme Court held that the FSIA did not answer the act of state issues in one case because the FSIA was a jurisdictional provision that did not change antecedent rights of sovereign nations. ${ }^{175}$ In 1976, just prior to the enactment of the FSIA, only a plurality of four Justices of the Supreme Court agreed that the Tate Letter and the developing international and national law of sovereign immunity removed the act of state issue from actions involving commercial activities of foreign sovereigns. ${ }^{176}$

\section{The Nature of the Immunity: Not a Right, but a Privilege Extended by Comity}

The courts consistently have acknowledged the principle that sovereign immunity was not a right owed to a foreign sovereign, but merely a privilege extended by the grace of a territorial sovereign, and that all the territorial sovereign had to do to withdraw the privilege was to give notice to the world that it would not afford the privilege of immunity from suit to foreign sovereigns. ${ }^{177}$ Unlike Eleventh Amendment immunity, the "privileged position of a foreign state is not an explicit command of the Constitution. It rests on considerations of policy given legal sanction by [the Supreme] Court."178 The Supreme Court interpreted the holding of The Schooner Exchange on this point as follows:

172. Sabbatino, 376 U.S. at $420,439$.

173. 22 U.S.C. $\$ 2370(\mathrm{e})(2)(2000)$.

174. E.g., First Nat'l City Bank, 462 U.S. at 633-34; Chase Manhattan Bank, 658

F.2d at 884; Chem. Bank N.Y. Trust Co., 822 F.2d at 236.

175. First Nat'l City Bank, 462 U.S. at 620-21.

176. Alfred Dunhill of London, Inc. v. Republic of Cuba, 425 U.S. 682, 696-705

(1976) (opinion of White, J., joined by Berger, Ch. J., Powell, J., and Rehnquist, J.).

177. Dole Food Co. v. Patrickson, 123 S. Ct. 1655, 1663 (2003); Verlinden B.V. v. Cent. Bank of Nig., 461 U.S. 480, 486 (1983); The Santissima Trinidad, 20 U.S. (7 Wheat.) $283,352-53$ (1822). The sovereign immunity granted to individual states of the United States differs from that afforded to foreign nations. See Caleb Nelson, Sovereign Immunity as a Doctrine of Personal Jurisdiction, 115 HaRv. L. REv. 1559 (2002).

178. Nat'l City Bank of N.Y. v. Republic of China, 348 U.S. 356, 358-59 (1955); see also Verlinden B.V., 461 U.S. at 486; Nelson, supra note 177, at 1619. 
It was there shown that it was not founded upon any notion that a foreign sovereign had an absolute right, in virtue of his sovereignty, to an exemption of his property from the local jurisdiction of another sovereign, when it came within his territory; for that would be to give him sovereign power beyond the limits of his own empire. But it stands upon principles of public comity and convenience, and arises from the presumed consent or license of nations, that foreign public ships coming into their ports, and demeaning themselves according to law, and in a friendly manner, shall be exempt from the local jurisdiction. But as such consent and license is implied only from the general usage of nations, it may be withdrawn upon notice at any time, without just offence, and if afterwards such public ships come into our ports, they are amenable to our laws in the same manner as other vessels. ${ }^{179}$

This principle is still followed today. ${ }^{180}$

The Supreme Court has distinguished the privilege of sovereign immunity from status-based rights to immunity, such as legislative immunity, judicial immunity, and presidential immunity. ${ }^{181}$ Unlike these status-based immunities, which provide a legal entitlement to immunity based on one's position and the necessity not to be inhibited in official functions by the threat of lawsuits arising from actions undertaken within the scope of the office's duties, sovereign immunity is not a right belonging to a foreign nation and its agencies and instrumentalities based on its status as a sovereign nation. ${ }^{182}$ Instead, it is purely a matter of comity that is extended by the grace of the territorial sovereign, ${ }^{183}$ and can be withdrawn or amended at any time.

179. The Santissima Trinidad, 20 U.S. (7 Wheat.) at 352-53.

180. See, e.g., Verlinden B.V., 461 U.S. at 486; First Nat'l City Bank v. Banco Para el Comercio Exterior de Cuba, 462 U.S. 611, 626-27 (1983); Nat'l City Bank of N.Y., 348 U.S. at 359. See also New Eng. Merchs. Nat'l Bank v. Iran Power Generation \& Transmission Co., 502 F. Supp. 120, 129 (S.D.N.Y. 1980), aff'd, 646 F.2d 779 (2d Cir. 1981), aff'd sub nom. Iran Nat'l Airlines Corp. v. Marschalk Co., 453 U.S. 919 (1981) ("Sovereign immunity is granted to foreign governments as a matter of comity. While it is a well-established doctrine, it is clear that it is a privilege granted by one sovereign to another in the family of nations. It is not now nor has it ever been a right enjoyed by one sovereign within the territorial jurisdiction of another. The fact that the doctrine has now been codified in the [FSIA] does not alter this fundamental premise. To be sure, sovereign immunity is a privilege enjoyed by a foreign nation rather than an inalienable right to which it can lay claim.") (citations omitted).

181. Dole Food, 123 S. Ct. at 1662-63.

182. Id.

183. Id. 
III.

The Foreign Sovereign Immunities ACt

In 1976, Congress passed the Foreign Sovereign Immunities Act in order to free the government from the case-by-case diplomatic pressures, to clarify the governing standards, and to "assur[e] litigants that ... decisions are made on purely legal grounds and under procedures that insure due process."184 The FSIA codified into federal statutory law the restrictive theory of sovereign immunity that was developed and adopted by the United States in the twentieth century. ${ }^{185}$ In addition, the FSIA addressed the uncertainties of the Department of State's policies $^{186}$ with regard to providing suggestions regarding a foreign nation's sovereign immunity that seemed to fly in the face of the restrictive theory of immunity, ${ }^{187}$ or by providing the cryptic statements of "no comment," as seen in The Navemar and Sabbatino cases. ${ }^{188}$

According to the legislative history, the statute was designed to accomplish four objectives: (1) to codify the "restrictive" principle of sovereign immunity adopted by the Department of State in $1952 ; 189$ (2) to insure that the restrictive principle of immunity is applied in litigation before U.S. courts; ${ }^{190}$ (3) to provide a statutory procedure for effecting service upon, and obtaining in personam jurisdiction over, a

184. H.R. REP. No. 94-1487, at 7 (1976), reprinted in 1976 U.S.C.C.A.N. 6604, 6606.

185. See Verlinden B.V., 461 U.S. at 488-89. For a detailed history of the enactment of the FSIA, see WRIGHT ET AL., supra note 10, $\$ 3662$, at 216.

186. See WRIGHT ET AL., supra note 10, § 3662, at 216.

187. E.g., Spacil v. Crowe, 489 F.2d 614, 617 (5th Cir. 1974); Isbrandtsen Tankers, Inc. v. President of India, 446 F.2d 1198, 1200 (2d Cir. 1971); Heaney v. Gov't of Spain, 445 F.2d 501, 503 (2d Cir. 1971).

188. Compania Espanola de Navegacion Maritima v. The Navemar, 303 U.S. 68, 75-76 (1938); Banco Nacional de Cuba v. Sabbatino, 376 U.S. 398, 399 (1963).

189. H.R. REP. No. 94-1487, at 7 (1976), reprinted in 1976 U.S.C.C.A.N. 6604, 6605 ("First, the bill would codify the so-called 'restrictive' principle of sovereign immunity, as presently recognized in international law. Under this principle, the immunity of a foreign state is 'restricted' to suits involving a foreign state's public acts (jure imperii) and does not extend to suits based on its commercial or private acts (jure gestionis). This principle was adopted by the Department of State in 1952 and has been followed by the courts and by the executive branch ever since. Moreover, it is regularly applied against the United States in suits against the U.S. Government in foreign courts."). In the paragraph quoted here, the House Report repeats the popular misconception that the 1952 Tate Letter inaugurated the American doctrine of restrictive immunity rather than tracing the doctrine back to the Marshall Court decisions, and states that the doctrine was "followed by the courts and by the executive branch ever since," which is inconsistent with the actual record. Id. at 7, reprinted in 1976 U.S.C.C.A.N. 6604, 6605.

190. Id. at 7, reprinted in 1976 U.S.C.C.A.N. 6604, 6605-06. 
foreign state; ${ }^{191}$ and (4) to remedy, in part, the problems faced by plaintiffs who have obtained judgments against foreign states. ${ }^{192}$

The FSIA amended Title 28 of the United States Code to remove the earlier provision in 28 U.S.C. $\$ 1332$ (a) which had allowed diversity jurisdiction in federal courts over claims involving citizens of a state and a foreign state, and replaced it with the provision codified at 28 U.S.C. $\$ 1330(a)$, providing for "original jurisdiction without regard to amount in controversy of any nonjury civil action against a foreign state ...."193 Section 1332(a)(4) of Title 28 still provides jurisdiction over a suit in which a foreign state is a plaintiff against citizens of a state or of different states in which the amount in controversy requirement is met. ${ }^{194}$ The FSIA also amended the removal jurisdiction statute, 28 U.S.C. $\S 1441(\mathrm{~d})$, to provide for removal to federal court of actions brought against foreign states in state court. ${ }^{195}$

The FSIA has, in effect, provided a federal long-arm statute in 28 U.S.C. $\S 1330$ (b) for asserting personal jurisdiction over foreign states, including political subdivisions, agencies, and instrumentalities of foreign states. ${ }^{196}$ If none of the exceptions to sovereign immunity set forth in the FSIA applies, the court lacks both statutory subject matter jurisdiction and personal jurisdiction. ${ }^{197}$

The FSIA addresses what constitutes a foreign state under the sovereign immunity provisions:

(a) A "foreign state", except as used in section 1608 of this title, includes a political subdivision of a foreign state or an agency or instrumentality of a foreign state as defined in subsection (b).

(b) An "agency or instrumentality of a foreign state" means any entity-

(1) which is a separate legal person, corporate or otherwise, and

(2) which is an organ of a foreign state or political subdivision thereof, or a majority of whose shares or other ownership interest is owned by a foreign state or political subdivision thereof, and

191. Id. at 8 , reprinted in 1976 U.S.C.C.A.N. $6604,6606$.

192. Id. at 8, reprinted in 1976 U.S.C.C.A.N. 6604, 6606; WRIGHT ET AL., supra note $10, \S 3662$, at 216 .

193. 28 U.S.C. $\$ 1330$ (a) (2000); WRIGHT ET AL., supra note 10 , 33662 , at 215 .

194. 28 U.S.C. $\S 1332(a)(4)(2000)$; WRIGHT ET AL., supra note 10, § 3662, at 215 . 195. 28 U.S.C. $\S 1441$ (d) (2000); WRIGHT ET AL., supra note 10 , 33662 , at 215-16. 196. See WRIGHT ET AL., supra note $10, \S 3662$, at 215 ; Vermeulen v. Renault, U.S.A., Inc., 985 F.2d 1534, 1553 (11th Cir. 1993); Nat'l Am. Corp. v. Fed. Republic of Nig., 48 F. Supp. 622, 638 (S.D.N.Y. 1978), aff'd, 597 F.2d 314 (2d Cir. 1979). 197. See Verlinden B.V. v. Cent. Bank of Nig., 461 U.S. 480, 489 (1983). 
(3) which is neither a citizen of a State of the United States as defined in section 1332(c) and (d) of this title, nor created under the laws of any third country. ${ }^{198}$

Section 1604 lays out the basic scheme for the allowance of immunity to foreign states:

Subject to existing international agreements to which the United States is a party at the time of enactment of this Act a foreign state shall be immune from jurisdiction of the courts of the United States and of the States except as provided in sections 1605 to 1607 of this chapter. ${ }^{199}$

Section 1605 then provides the exceptions to sovereign immunity of foreign states:

(a) A foreign state shall not be immune from the jurisdiction of courts of the United States or of the States in any case-

(1) in which the foreign state has waived its immunity either explicitly or by implication, notwithstanding any withdrawal of the waiver which the foreign state may purport to effect except in accordance with the terms of the waiver;

(2) in which the action is based upon a commercial activity carried on in the United States by the foreign state; or upon an act performed in the United States in connection with a commercial activity of the foreign state elsewhere; or upon an act outside the territory of the United States in connection with a commercial activity of the foreign state elsewhere and that act causes a direct effect in the United States;

(3) in which rights in property taken in violation of international law are in issue and that property or any property exchanged for such property is present in the United States in connection with a commercial activity carried on in the United States by the foreign state; or that property or any property exchanged for such property is owned or operated by an agency or instrumentality of the foreign state and that agency or instrumentality is engaged in a commercial activity in the United States . . . . 200

198. 28 U.S.C. $\S 1603(\mathrm{a})-(\mathrm{b})$ (2000).

199. Id. § 1604 .

200. Id. $\S 1605(\mathrm{a})(1)-(3)$. Section 1605 (a) goes on to provide exceptions for the following actions:

(4) in which rights in property in the United States acquired by succession or gift or rights in immovable property situated in the United States are in issue;

(5) ... in which money damages are sought against a foreign state for personal injury or death, or damage to or loss of property, occurring in the United States. ...

.... 
The expropriation exception in section $1605(a)(3)$ is the primary focus of my analysis in this article. In order to establish jurisdiction pursuant to the FSIA expropriation exception, a plaintiff must demonstrate: "(1) that rights in property are in issue; (2) that the property was 'taken'; (3) that the taking violated international law; and (4) that one of the two jurisdictional nexus requirements is satsified."201 To establish the necessary jurisdictional nexus with the United States, the property must "either (a) be present in the United States in connection with a commercial activity carried on in the United States by the foreign state, or (b) be owned or operated by an agency or instrumentality of the foreign state that is engaged in a commercial activity in the United States."202

A right in property, within the meaning of the FSIA, is generally held to be a right in "physical property" as opposed to a right to receive payments, ${ }^{203}$ or even an intangible property interest, such as minority share ownership in a corporation, that is not within the

(6) in which the action is brought, either to enforce an agreement made by the foreign state with or for the benefit of a private party to submit to arbitration. ...

(7) . . in which money damages are sought against a foreign state for personal injury or death that was caused by an act of torture, extrajudicial killing, aircraft sabotage, hostage taking, or the provision of material support or resources ... except that the court shall decline to hear a claim under this paragraph-

(A) if the foreign state was not designated as a state sponsor of terrorism....

(b) A foreign state shall not be immune from the jurisdiction of the courts of the United States in any case in which a suit in admiralty is brought to enforce a maritime lien against a vessel or cargo of the foreign state, which maritime lien is based upon a commercial activity of the foreign state. . . .

(d) A foreign state shall not be immune from the jurisdiction of the courts of the United States in any action brought to foreclose a preferred mortgage, as defined in the Ship Mortgage Act . . . .

Id. $\S 1605(\mathrm{a})(4)-(7)$. Section 1607 provides an exception for counterclaims asserted in suits initiated in U.S. courts by foreign sovereigns. Id. $\S 1607$.

201. Zappia Middle E. Constr. Co. v. Emirate of Abu Dhabi, 215 F.3d 247, 251 (2d Cir. 2000); see also Lord Day \& Lord v. Socialist Republic of Vietnam, 134 F. Supp. 2d 549, 560 (S.D.N.Y. 2001).

202. De Sanchez v. Banco Cent. de Nicar., 770 F.2d 1385, 1395 n.12 (5th Cir. 1985). 203. E.g., Hirsh v. State of Israel, 962 F. Supp. 377, 383 (S.D.N.Y. 1997) and Canadian Overseas Ores Ltd. v. Compania de Acero del Pacifico, 528 F. Supp. 1337, 1346 (S.D.N.Y. 1982) (holding that contractual rights to payment, absent expropriation of real property, do not constitute "property" within meaning of FSIA). 
claimant's exclusive control. ${ }^{204}$ Breach of a commercial contract alone does not constitute a taking pursuant to international law. ${ }^{205}$

The term "taken" is not defined in the FSIA. According to the legislative history, however, "taken in violation of international law" denotes "the nationalization or expropriation of property without payment of the prompt adequate and effective compensation required by international law."206 This includes "takings which are arbitrary or discriminatory in nature."207 Therefore, "taken" refers not to acts of a private enterprise, but to acts of a sovereign which deprive a plaintiff of property without adequate compensation. ${ }^{208}$

Courts will likely conclude that an act of expropriation violates international law if it does not serve a public purpose, if it is discriminatory, particularly against aliens on the basis of their nationality or ethnicity, or if it is not followed by payment of just compensation. ${ }^{209}$ The United States has asserted consistently that just compensation means compensation that is "prompt, adequate and effective."210

Altmann v. Republic of Austria, an ongoing case, demonstrates a useful picture of the type of situation covered by the expropriation exception. In this case, Maria Altmann seeks to recover ownership and possession of six paintings by the world-renowned artist Gustav Klimt, which the Nazis stole in the early 1940s from her family in Austria, and which currently are possessed by the Austrian Gallery, an instrumentality of the Republic of Austria. ${ }^{211}$ The facts of Altmann represent a vivid example of the large-scale art theft perpetrated against Jews and other subject nationalities by the forces of the Third Reich.

204. Kalamazoo Spice Extraction Co. v. Provisional Military Gov't of Socialist Ethiopia, 616 F. Supp. 660, 663 (W.D. Mich. 1985) (finding that majority stock interest, which conferred control over physical assets of company, fell within exception).

205. Zappia, 215 F.3d at 252; First Fid. Bank v. Gov't of Antigua \& Barbuda, 877 F.2d 189, 193 (2d Cir. 1989).

206. H.R. REP. No. 94-1487, at 19-20 (1976), reprinted in 1976 U.S.C.C.A.N. 6604, 6618; Zappia, 215 F.3d at 251.

207. H.R. REP. No. 94-1487, at 20 (1976), reprinted in 1976 U.S.C.C.A.N. 6604, 6618; Zappia, 215 F.3d at 251.

208. Zappia, 215 F.3d at 251; see also Alfred Dunhill of London, Inc. v. Republic of Cuba, 425 U.S. 682, 685 (1976).

209. See, e.g., Siderman de Blake v. Republic of Argentina, 965 F.2d 699, 711-12 (9th Cir. 1992); West v. Multibanco Comermex, S.A., 807 F.2d 820, 831-832 (9th Cir. 1987); see also RestATEMENT, supra note $7, \S 712(1)$, $\$ 712 \mathrm{cmt}$. f.

210. See Restatement, supra note 7 , $\$ 712 \mathrm{cmt}$. c; H.R. ReP. No. 94-1487, at 19-20, reprinted in 1976 U.S.C.C.A.N. 6604, 6618.

211. Altmann v. Republic of Austria, 317 F.3d 954, 959-60 (9th Cir. 2002) (Altmann II), cert. granted, 124 S. Ct. 46 (2003). 
The paintings at issue were owned by Ferdinand Bloch-Bauer, the plaintiff's uncle. Ferdinand left Austria in 1938, after the Nazi invasion and the resulting anschluss of Austria. ${ }^{212}$ The Nazis took his home, his sugar business, and his artwork, and four hundred pieces of his vast porcelain collection were sold at public auction. ${ }^{213}$ Several nineteenth-century Austrian paintings went to Adolf Hitler's and Herman Göring's private collections. ${ }^{214}$ Dr. Erich Fuerher, a Nazi lawyer responsible for liquidating Ferdinand's collection, also selected a few works for his own collection. ${ }^{215}$ Two of the paintings at issue in the case, Adele Bloch-Bauer I and Apple Tree I, were given by Dr. Fuerher to the Austrian Gallery in 1941, in exchange for a painting, Schloss Kammer am Attersee III, that Ferdinand had donated in 1936. ${ }^{216}$ This purported gift was accompanied by a note, signed "Heil Hitler," in which Dr. Fuerher claimed to be making the donation in fulfillment of Adele Bloch-Bauer's last will and testament. ${ }^{217} \mathrm{Dr}$. Fuerher sold Beechwood in November 1942 to the Museum of the City of Vienna, and in March 1943, he sold Adele Bloch-Bauer II to the Austrian Gallery. Schloss Kammer am Attersee III was later sold to Gustav Klimt's son, and in 1961 it was donated to the Austrian Gallery. ${ }^{218}$

Although Ferdinand died soon after the war in Europe ended, he had taken preliminary steps to retrieve his stolen property. ${ }^{219}$ The Austrian Republic enacted a law in 1946 deeming all transactions that were motivated by discriminatory Nazi ideology to be null and void. ${ }^{220}$ The Republic, however, often required the original owners of such property to repay the purchase price to the purchaser before an item would have to be returned. ${ }^{221}$ In addition, the Republic effectively extorted "donations" of certain works of art from the claimant's family in exchange for export permits to allow the removal of other artworks from the country. ${ }^{222}$ The Altmann courts found that these

212. Altmann v. Republic of Austria, 142 F. Supp. 2d 1187, 1193 (C.D. Cal. 2001) (Altmann I), aff'd, 317 F.3d 954 (9th Cir. 2002) (Altmann II), cert. granted, 124 S. Ct. 46 (2003).

213. Id.

214. Altmann II, 317 F.3d at 959.

215. Id.

216. See id.; Altmann l, 142 F. Supp. 2d at 1193.

217. Altmann II, 317 F.3d at 959-60.

218. Altmann I, 142 F. Supp. $2 d$ at 1193 n.6.

219. Id. at 1193 .

220. Id.

221. Id.

222. See Altmann II, 317 F.3d at 960. 
allegations established a prima facie case for jurisdiction under the expropriation clause of the FSIA. ${ }^{223}$

The arguments raised against jurisdiction in the Altmann line of cases mirror those raised by the defendants in other FSIA cases involving pre-1952 facts, such as Joo, ${ }^{224}$ Jackson, ${ }^{225}$ Carl Marks, ${ }^{226}$ and Princz, ${ }^{227}$ namely:

1. Whether the FSIA is a jurisdictional statute that applies to actions arising from operative facts that occurred before or after the effective date of the statute or the 1952 Tate Letter without regard to when the action accrued;

2. Whether the FSIA is a procedural statute that applies to actions arising from operative facts that occurred before the effective date of the statute and before 1952 because it does not affect antecedent rights of the parties and thus is not retroactive;

3. If the application of the FSIA to pre-enactment conduct or to pre-1952 conduct does in fact affect substantive rights of state parties, namely rights to sovereign immunity under customary international law, whether the retroactive application of the statute was clearly indicated and intended by Congress based on the terms of the FSIA and its legislative history; and

4. Whether the conduct of the Nazi regime and its agencies and instrumentalities in World War II should have defeated the expectations of these state parties that they would receive immunity from prosecution in foreign courts, thus refuting the claim that retroactive application of the FSIA actually violates substantive rights under customary international law.

The following sections address these issues in turn, and conclude that the FSIA does apply to provide jurisdiction over suits arising from pre-1952 war crimes involving plunder and expropriation.

223. See Altmann I, 142 F. Supp. 2d at 1203; Altmann II, 317 F.3d at 959.

224. Joo v. Japan, 332 F.3d 679, 687 (D.C. Cir. 2003) (holding FSIA inapplicable to WWII-era suit against Japan for abuse of "comfort women").

225. Jackson v. People's Republic of China, 794 F.2d 1490, 1491 (11th Cir. 1986) (holding that FSIA did not apply retroactively to suit arising from 1911 Chinese bond issue).

226. Carl Marks \& Co. v. Union of Soviet Socialist Republics, 665 F. Supp. 323, 336-42 (S.D.N.Y. 1987), aff'd, 841 F.2d 26 (2d Cir. 1988) (holding that FSIA did not apply retroactively to suit arising from 1916 Russian Imperial Bond issue).

227. Princz v. Fed. Republic of Germany, 26 F.3d 1166, 1170-71 (D.C. Cir. 1994) (finding strong arguments in favor of applying FSIA retroactively, but, not faced with retroactivity issue directly, declining to rule on FSIA's applicability in suit against Germany arising from WWII internment in concentration camps). 
IV.

The FSIA is a Jurisdictional Statute

Since the very beginning, the concept of sovereign immunity has primarily concerned the jurisdiction of the courts, not the substantive issues involving liability of foreign states for their actions or involving justiciability of issues pertaining to the actions of a foreign government (the act of state doctrine) or foreign heads of state (the head of state doctrine). Chief Justice Marshall in The Schooner Exchange made his determination on the basis of jurisdiction, ${ }^{228}$ and found that the justiciability argument was not worthy of extended discussion. ${ }^{229}$ The Schooner Exchange Court stated:

The jurisdiction of courts is a branch of that which is possessed by the nation as an independent sovereign power.

The jurisdiction of the nation within its own territory is necessarily exclusive and absolute. It is susceptible of no limitation not imposed by itself. Any restriction upon it, deriving validity from an external source, would imply a diminution of its sovereignty to the extent of the restriction, and an investment of that sovereignty to the same extent in that power which could impose such restriction. ${ }^{230}$

There was no question in the Court's mind of the power of courts to hear these cases. ${ }^{231}$ At issue was not whether states had a right to sovereign immunity within the territory of another sovereign, but whether it was appropriate for the territorial sovereign to refrain from exercising jurisdiction over actions involving a friendly foreign sovereign out of respect for his sovereignty and as a matter of comity and good offices. ${ }^{232}$

The Santissima Trinidad confirmed that courts were competent to hear cases involving foreign sovereigns as a matter of jurisdictional power, and that the fact that a foreign sovereign appears voluntarily or feels compelled by circumstances to join an action as a suitor to protect his private interests does not oust the court of its jurisdiction over the matter. ${ }^{233}$ The Court went on to find that it was appropriate for the district court to maintain jurisdiction over the alleged prize of a foreign sovereign, as the seeking of prizes was a private activity of a

228. The Schooner Exchange v. McFaddon, 11 U.S. ( 7 Cranch) 116, 136-37 (1812).

229. Id. at 146.

230. Id. at 136.

231. See id.

232. Id. at 136-37.

233. The Santissima Trinidad, 20 U.S. (7 Wheat.) 283, 353-54 (1822). 
foreign state rather than a public activity for which jurisdiction might be withheld. ${ }^{234}$

The Supreme Court continued to view the issue of sovereign immunity as one of jurisdiction in the twentieth century. Ex parte Muir, ${ }^{235}$ Pesaro I, ${ }^{236}$ Pesaro II, ${ }^{237}$ and Pesaro III ${ }^{238}$ each determined the issue of sovereign immunity as a jurisdictional issue. Chief Justice Stone's trilogy of The Navemar, ${ }^{239}$ Ex parte Peru, ${ }^{240}$ and Hoffman ${ }^{241}$ each held that sovereign immunity was an issue of jurisdiction rather than justiciability, and held that the courts were competent to determine the issues of immunity from jurisdiction with or without the input of the executive branch. ${ }^{242}$ After 1952, courts continued to regard sovereign immunity as a jurisdictional issue. ${ }^{243}$

The FSIA did not create, but merely codified, the law of sovereign immunity. ${ }^{244}$ It did not create jurisdiction where none existedit merely clarified the circumstances in which courts would and would not exercise jurisdiction over foreign sovereigns, and took the decision-making authority regarding this determination away from the executive branch and placed it firmly within the purview of the courts. ${ }^{245}$

234. See id. at $352-53$.

235. 254 U.S. 522, 532 (1921).

236. The Pesaro, 255 U.S. 216, 217-18 (1921).

237. The Pesaro, 277 F. 473,473 (S.D.N.Y. 1921).

238. Berizzi Bros. Co. v. The Pesaro, 271 U.S. 562, 570 (1926).

239. 303 U.S. 68,69 (1938).

240. 318 U.S. $578,587-88$ (1943).

241. 324 U.S. 30,32 (1945).

242. E.g., Hoffman, 324 U.S. at 34-35 ("In the absence of recognition of the claimed immunity by the political branch of the government, the courts may decide for themselves whether all the requisites of immunity exist."); Ex parte Peru, 318 U.S. at 587 ("Here the district court acquired jurisdiction in rem by the seizure and control of the vessel, and the libelant's claim against the vessel constituted a case or controversy which the court had authority to decide. Indeed, for the purpose of determining whether petitioner was entitled to the claimed immunity, the district court, in the absence of recognition of the immunity by the Department of State, had authority to decide for itself whether all the requisites for such immunity existed . ..."); Compania Espanola de Navegacion Maritima v. The Navemar, 303 U.S. 68, 75 (1938) ("[T]he want of admiralty jurisdiction because of the alleged public status of the vessel and the right of the Spanish Government to demand possession of the vessel as owner if it so elected, were appropriate subjects for judicial inquiry upon proof of the matters alleged.").

243. See, e.g., Nat'l City Bank of N.Y. v. Republic of China, 348 U.S. 356, 362 (1955); Victory Transp., Inc. v. Comisaria General de Abastecimientos y Transportes, 336 F.2d 354, 363 (2d Cir. 1964); Bernstein v. N.V. Nederlandsche-Amerikaansche Stoomvaart-Maatschappij, 210 F.2d 375, 375 (2d Cir. 1954).

244. See Verlinden B.V. v. Central Bank of Nig., 461 U.S. 480, 488 (1983).

245. H.R. REP. No. 94-1487, at 7-8 (1976), reprinted in 1976 U.S.C.C.A.N. 6604, 6605-06; WRIGHT ET AL., supra note $10, \S 3662$, at $160-61$. 
The Supreme Court interpreted the FSIA as removing the existing federal jurisdictional bases for suits against foreign sovereigns from the Alien Tort Statute, 28 U.S.C. § 1350; diversity jurisdiction, 28 U.S.C. § 1332(a); admiralty jurisdiction, 28 U.S.C. $\$ 1333$; interpleader, 28 U.S.C. $\S 1335$; commerce and antitrust, 28 U.S.C. $\S 1337$; and patents, copyrights, and trademarks, 28 U.S.C. $\S 1338$; and placing the exclusive basis for federal jurisdiction over suits against foreign sovereigns in 28 U.S.C. $\S 1330 .{ }^{246}$ Thus, the FSIA removed jurisdiction over foreign sovereigns from these various other categories of federal jurisdiction and placed it within a new category of federal question jurisdiction, supported by the fact that suits against foreign sovereigns invariably involve federal issues of U.S. foreign policy and international law, making them proper topics for Article III "arising under" federal question jurisdiction. ${ }^{247}$ In this respect, the FSIA is a quintessential jurisdiction-allocating statute.

Courts apply newly enacted jurisdiction-allocating statutes to pending cases because the circumstances fail to implicate the conditions for the general presumption against retroactivity. ${ }^{248}$ As stated in Landgraf v. USI Film Products:

Application of a new jurisdictional rule usually "takes away no substantive right but simply changes the tribunal that is to hear the case." Present law normally governs in such situations because jurisdictional statutes "speak to the power of the court rather than to the rights or obligations of the parties." 249

And in Hughes Aircraft, the Court stated that "[s]tatutes merely addressing which court shall have jurisdiction to entertain a particular cause of action can fairly be said merely to regulate the secondary conduct of litigation and not the underlying primary conduct of the parties." 250

Although the Supreme Court has not ruled directly on the issue of retroactivity and the FSIA, the concept has been involved in several cases. The Court in First National City Bank did not question the applicability of the FSIA to conduct (Cuban expropriations) occurring

246. Argentine Republic v. Amerada Hess Shipping Corp., 488 U.S. 428, 437-38 (1989).

247. Verlinden, 461 U.S. at 493-94. Suits initiated by foreign states still may be brought under the diversity jurisdiction statute, 28 U.S.C. $\$ 1332(a)(4)$.

248. See Hughes Aircraft Co. v. United States ex rel. Schumer, 520 U.S. 939, 951 (1997).

249. 511 U.S. $244,274-75$ (1994) (citations omitted).

250. Hughes Aircraft, 520 U.S. at 951. 
in 1960-61.251 The Verlinden Court did not question the applicability of the FSIA to transactions occurring in 1975.252 Earlier, in reference to the Tate Letter of 1952 that was codified into the FSIA, the $\mathrm{Na}$ tional City Bank of New York Court applied the principles of the 1952 letter to transactions occurring in 1920 and 1947-48. ${ }^{253}$

In 1983, the Supreme Court ruled that the FSIA did not answer the act of state issues in the case because the FSIA was a jurisdictional provision that did not change antecedent rights of sovereign nations. ${ }^{254}$ This contrasts with Hughes Aircraft, in which an amendment to a jurisdictional provision of the federal False Claims Act removed the bar to qui tam actions that arose from facts previously reported to the government. ${ }^{255}$ This amendment took away an affirmative defense possessed by the government contractor defendants, and in effect created a new qui tam cause of action for false claims previously disclosed to the government where none had existed before. ${ }^{256}$

The FSIA also contrasts with the Landgraf case, in which provisions of Civil Rights Act of 1991, creating the right to recover compensatory and punitive damages for certain violations of Title VII, substantially changed defendants' exposure to liability and increased the damages to which defendants might be called upon to pay, and thus attached new legal consequences to events completed before its enactment. ${ }^{257}$ In contrast to the provision in the 1991 Act that provided for a jury trial in cases in which compensatory damages were claimed, which the Supreme Court held to be a purely procedural change, the provision providing for the recovery of compensatory damages created a new cause of action for monetary relief for persons who were victims of a hostile work environment but were not constructively discharged, and it created a new potential liability for damages for their employers. ${ }^{258}$ Thus, the Act was not a purely procedural or jurisdictional provision that could be applied to pending actions arising from facts predating the effective date of the statute.

251. First Nat'l City Bank v. Banco Para el Comercio Exterior de Cuba, 462 U.S. 611, 619-21 (1983).

252. 461 U.S. at $483-89$.

253. 348 U.S. at 357-66. Similarly, in 1954 the Bernstein court applied the principles stated in the 1949 Tate Letter to Nazi conduct which occurred before and during World War II (1937-42). Bernstein v. N.V. Nederlandsche-Amerikaansche Stoomvaart-Maatschappij, 210 F.2d 375, 375-76 (2d Cir. 1954).

254. First Nat'l City Bank, 462 U.S. at 620-21.

255. Hughes Aircraft, 520 U.S. at 946.

256. Id. at $948-50$.

257. Landgraf v. USI Film Prods., 511 U.S. 244, 250, 282-83 (1994).

258. Id. at 283 . 
The FSIA did not take away an affirmative defense of foreign sovereigns and did not change the legal consequences of acts completed before the effective date of the statute. Sovereign immunity always has been regarded as a matter of comity and grace extended by the good will of a territorial sovereign, never as a right of the foreign sovereign that supports a demand that the jurisdiction of the territorial courts be withdrawn. Prior to the enactment of the FSIA and prior to the 1952 Tate Letter, the jurisdictional power of U.S. courts to entertain suits involving foreign sovereigns was not questioned, ${ }^{259}$ and in the absence of proper suggestions of immunity asserted through proper channels, jurisdiction over the foreign states remained intact in spite of the foreign governments' attempts to communicate a defense of immunity through other channels. ${ }^{260}$ Recommendations of the State Department were not consistently made-sometimes a negative recommendation was made, sometimes a request was communicated without comment on the merits of the claim, and sometimes the executive branch simply was silent in the face of requests. A favorable suggestion of immunity depended on the good will and good relations between the United States and the foreign sovereign at the time of the suit, not at the time of the events from which the suit arose. ${ }^{261}$ Nothing in the history of sovereign immunity in the United States supports a vested right of a foreign sovereign to assert an affirmative defense of absolute immunity in United States courts.

The Supreme Court has followed this history by interpreting the FSIA as a jurisdictional provision requiring the courts to evaluate the state of affairs of the foreign sovereign at the time of suit, not at the time when the events occurred. ${ }^{262}$ The defendant in Dole Food attempted to assert an affirmative defense based on its status as a foreign state-owned enterprise at the time when the events of the suit occurred. ${ }^{263}$ The Court rejected the claim, noting that the defendant

259. See supra notes $228-242$ and accompanying text.

260. See, e.g., Compania Espanola de Navegacion Maritima v. The Navemar, 303 U.S. 68 (1938); The Gul Djemal, 264 U.S. 90 (1924); Ex parte Hussein Lutfi Bey, 256 U.S. 616 (1921); Ex parte Muir, 254 U.S. 522 (1921); The Pesaro, 255 U.S. 216 (1921) (Pesaro I).

261. See, e.g., Ex parte Peru, 318 U.S. 578, 588 (1943) (noting Court's consideration of good relations between Peru and United States at time of suit); The Navemar, 303 U.S. at 75-76 (considering status of ship requisitioned by Spanish government at time of suit); The Gul Djemal, 264 U.S. at 91 (considering status of Turkish ship in light of breakoff in relations between United States and Ottoman Turkey at time of suit); $E x$ parte Hussein Lutfi Bey, 256 U.S. at 618-19 (same); Ex parte Muir, 254 U.S. at 523 (considering British requisition of ship for use as admiralty transport at time of suit). 262. See Dole Food Co. v. Patrickson, 123 S. Ct. 1655, 1662-63 (2003).

263. Id. at 1662 . 
ceased to be majority-owned and controlled by a foreign state at the time the suit was filed, and thus held that the defendant failed to meet the definition of an agency or instrumentality of a foreign sovereign under 28 U.S.C. $\S 1603(b)(2) .{ }^{264}$ The Court stated that the ruling was "consistent with the "longstanding principle that the jurisdiction of the Court depends upon the state of things at the time of the action brought." "265

Cases that have rejected the argument that the FSIA is a purely jurisdictional provision have ignored the law, history and United States practice of sovereign immunity embodied in the FSIA. The Second Circuit decision in Amoco Overseas Oil Co. v. Compagnie Nationale Algerienne de Navigation is inapposite, because it held that section 1610 of the FSIA did not apply in a suit pending on the effective date of the Act because the operative language of this section states: "property . . . [shall not be] immune from attachment . . . after the effective date of the Act."266 This clearly indicates that this particular provision of the FSIA was to have a prospective application.

The Second Circuit took up the issue again in Corporacion Venezolana de Fomento v. Vintero Sales Corp., disagreeing with the lower court that the FSIA applied retroactively to confer jurisdiction over a suit pending on the FSIA's effective date, but, because it found an alternate source of federal jurisdiction, failing to discuss its reasons in depth. ${ }^{267}$

Carl Marks \& Co. v. Union of Soviet Socialist Republics and Jackson v. People's Republic of China took issue with the proposition that the FSIA did not disturb settled expectations rising to the level of

264. Id. at 1663 .

265. Id. at 1662 (quoting Keene Corp. v. United States, 508 U.S. 200, 207 (1993) (quoting Mollan v. Torrance, 22 U.S. (9 Wheat.) 537, 539 (1824))).

266. 605 F.2d 648, 654 (2d. Cir. 1979); 28 U.S.C. $\$ 1610$ (2002). The Court distinguished Yessenin-Volpin v. Novosti Press Agency, 443 F. Supp. 849 (S.D.N.Y. 1978), and Nat'l Am. Corp. v. Fed. Republic of Nigeria, 448 F. Supp. 622, 638-39 (S.D.N.Y. 1978), which had applied the jurisdictional provisions of the act to an action pending on the effective date, on the basis of the "after the effective date" language which appears in 28 U.S.C. $\S 1610$ but not in 28 U.S.C. $\S \S 1330,1602$, and 1608. See Amoco Overseas, 605 F.2d at 653-54. The Amoco Overseas holding, however, actually supports the construction of the FSIA that the jurisdictional provisions of the FSIA were intended to apply to actions whose facts predate the enactment of the FSIA; if Congress saw fit to expressly limit the operation of certain provisions to a time after the effective date of the statute, it can logically be inferred that Congress intended provisions without this limitation to apply to suits arising from facts that predate the effective date. See discussion infra Part VI.

267. 629 F.2d 786, 790-91 (2d Cir. 1980). 
antecedent rights to immunity from suit in American courts, ${ }^{268}$ and thus are more properly discussed in Section IV below. These opinions remain intact and are good law within their respective circuits, even though courts have questioned the viability of their holdings after Landgraf. ${ }^{269}$

Since Landgraf, courts have increasingly recognized that the FSIA is a jurisdictional statute that consolidated jurisdiction from several federal jurisdictional provisions into one provision, and did not create a new forum where no competent forum existed before, nor did it change the substantive rights of foreign states under the United States law of sovereign immunity prior to 1952 and prior to the statute's effective date. ${ }^{270}$ Joo $v$. Japan ${ }^{271}$ is the most notable exception.

The Second Circuit remains a holdout. In Abrams v. Société Nationale des Chemins de Fer Français, the Second Circuit discussed the jurisdictional status of the FSIA in the context of claims against the French national railroad company for torts committed in the transportation of French holocaust victims to death camps during World War II. ${ }^{272}$ On appeal from the ruling of the trial court that the action should be dismissed because no exceptions to sovereign immunity from jurisdiction applied, regardless of the issue of retroactivity, the parties agreed that if the FSIA applied to the case, the trial court would have no jurisdiction because none of the exceptions to immunity in the act apply to the claims raised in the suit. ${ }^{273}$ The question posed by the plaintiffs-appellants on appeal was the retroactivity question avoided by the district court. The Second Circuit did not answer the question, but reversed and remanded the case, requiring the district

268. See Carl Marks \& Co. v. Union of Soviet Socialist Republics., 841 F.2d 26, 27 (2d Cir. 1988); Jackson v. People's Republic of China, 794 F.2d 1490, 1497-98 (11 th Cir. 1986).

269. E.g., Altmann v. Republic of Austria, 142 F. Supp. 2d 1187, 1201 (C.D. Cal. 2001) (Altmann I), aff'd, 317 F.3d 954 (9th Cir. 2002) (Altmann II), cert. granted, 124 S. Ct. 46 (2003); Haven v. Rzeczpospolita Polska (Republic of Poland), 68 F. Supp. 2d 943, 945-46 (N.D. Ill. 1999), aff'd, 215 F.3d 727 (7th Cir. 2000); Princz v. Fed. Republic of Germany, 26 F.3d 1166, 1170 (D.C. Cir. 1994).

270. See, e.g., Altmann II, 317 F.3d at 963-64 (holding that FSIA applies to Nazi plunder of artwork before and during WWII); Haven, 68 F. Supp. 2d at 944-46 (holding that FSIA applies to events during and shortly after end of WWII); Creighton Ltd. v. Gov't of Qatar, 181 F.3d 118, 121-24 (D.C. Cir. 1999) (holding that FSIA is jurisdictional statute and does not implicate retroactivity concerns under Landgraf standards); Crist v. Republic of Turkey, 995 F. Supp. 5, 9 (D.D.C. 1998) (holding that FSIA applies to events in 1974); Princz, 26 F.3d at 1170-71 (suggesting that FSIA is jurisdictional statute that does not implicate retroactivity concerns under Landgraf standards, but deciding case on other grounds).

271. 332 F.3d 679 (D.C. Cir. 2003).

272. 332 F.3d 173, 174-75 (2d Cir. 2003).

273. Id. at $174-75,179$. 
court to answer the retroactivity question directly by applying the two step Landgraf test ${ }^{274}$ and, in particular, to determine whether application of the test would alter the vested rights of the defendant under World War II-era law. ${ }^{275}$ The court indicated its view that Congress did not clearly express an intention to make the FSIA apply retroactively under step one of the Landgraf analysis, and appeared to cast doubt on a finding that the FSIA ultimately has no effect on the rights and liabilities of the parties with regard to their actions in the World War II holocaust era. ${ }^{276}$ Nevertheless, the court felt more information needed to be developed in the record regarding the expectations of a belligerent nation in World War II, and remanded the case for the development of this information to answer the retroactivity question. 277 The Second Circuit followed the same practice in the consolidated appeals from the dismissal of claims of Jews dispossessed of property in Poland and Austria during and after World War II in Garb v. Republic of Poland and Whiteman v. Republic of Austria. ${ }^{278}$

The Abrams, Garb and Whiteman cases in the Second Circuit seem to fly in the face of Dole Food. In Dole Food, the Supreme Court already determined that the FSIA is a jurisdictional statute providing a procedural, jurisdictional immunity rather than a substantive, status-based immunity. And, as a jurisdictional immunity statute, the relevant time period for evaluating the foreign sovereign's rights to immunity is the time of filing of the suit, not its status or expectations at the time the events of the action transpired.279 The defendant in Dole Food would have enjoyed immunity under the state instrumen-

274. Landgraf set out two steps to determine whether a statute operates in a retroactive manner:

When a case implicates a federal statute enacted after the events in suit, the court's first task is to determine whether Congress has expressly prescribed the statute's proper reach. If Congress has done so, of course, there is no need to resort to judicial default rules. When, however, the statute contains no such express command, the court must determine whether the new statute would have retroactive effect, i.e., whether it would impair rights a party possessed when he acted, increase a party's liability for past conduct, or impose new duties with respect to transactions already completed. If the statute would operate retroactively, our traditional presumption teaches that it does not govern absent clear congressional intent favoring such a result.

Landgraf v. USI Film Prods., 511 U.S. 244, 280 (1993).

275. Abrams, 332 F.3d at 185-87.

276. $I d$. at $184-85$.

277. Id. at $187-88$.

278. Garb v. Republic of Poland, Nos. 02-7844, 02-9361, 02-3087, 2003 WL 21890843 (2d Cir. Aug. 6, 2003), Whiteman v. Republic of Austria, No. 00 Civ. 8006(SWK), 2002 WL 31368236 (S.D.N.Y. Oct. 21, 2002).

279. Dole Food Co. v. Patrickson, 123 S. Ct. 1655, 1662-63 (2003). 
tality provisions of 28 U.S.C. $\S 1603$ if it had been sued at the time of the transactions from which the action arose because it was, at that time, a majority state-owned enterprise; the Supreme Court held, however, that the status at time of filing of the suit was all that mattered. ${ }^{280}$

This holding must be viewed in light of three other principles of sovereign immunity in United States law. First, the Supreme Court, since the time of The Schooner Exchange and The Santissima Trini$\mathrm{dad}$, has made abundantly clear that sovereign immunity was a privilege extended by comity in the interests of foreign policy and could be removed at any time by giving notice. ${ }^{281}$ Second, the executive branch gave notice to foreign states from time to time regarding the extension or withholding of immunity in certain situations-most important to the present analysis are the publications regarding the freedom of U.S. courts to adjudicate claims arising from the actions of Nazi Germany and its affiliates in World War II, ${ }^{282}$ and the later announcement reaffirming the executive branch's intent to follow the restrictive theory of sovereign immunity in the 1952 Tate Letter. The FSIA is yet another proclamation of the United States in this series informing the world of the terms under which the United States will and will not extend jurisdictional immunity to foreign sovereigns. Third, sovereign immunity decisions have always been made at the time of suit, and foreign sovereigns literally have sat at the mercy of the State Department, which would make suggestions or withhold suggestions based on the status of relations with the foreign power at the time of the suit, not at the time the events from which the suit arose transpired. ${ }^{283}$ Thus, any expectations as to immunity must have been formed at the time of suit, not at the time the operative events occurred. This is the principle affirmed recently in Dole Food. ${ }^{284} \mathrm{Al}-$ though no court has expressed this concept in these terms, there are examples of the Supreme Court applying the 1952 Tate Letter to conduct occurring in 1920 and 1947-48, and applying the FSIA to conduct occurring in 1960 and 1975 because the evaluation of immunity

280. Id.

281. See, e.g., The Schooner Exchange, 11 U.S. (7 Cranch) 116, 123 (1812); New Eng. Merchs. Nat'l Bank v. Iran Power Generation \& Transmission Co., 502 F. Supp. 120, 129 (S.D.N.Y. 1980), aff'd, 646 F.2d 779 (2d Cir. 1981), aff'd sub nom. Iran Nat'l Airlines Corp. v. Marschalk Co. Inc, 453 U.S. 919 (1981); Verlinden B.V. v. Central Bank of Nig., 461 U.S. 480, 486 (1983).

282. See supra text accompanying notes 142-147.

283. See Dole Food, $123 \mathrm{~S}$. Ct. at 1663.

284. Id. 
was made at the time of suit, not based on the time period when the action accrued. 285

In light of this analysis, in Abrams, Garb, and Whiteman, the Second Circuit may have sent the lower court on a wild goose chase. Any expectation of immunity must be formed at the time of suit, not at the time of the events from which the action arose. If this is the broader holding of Dole Food, which affirms the history of the United States law and practice of sovereign immunity summarized in the paragraph above, then the Second Circuit merely should evaluate what the defendants' expectations should have been at the time of filing of the suit, under the regime enacted in the FSIA. ${ }^{286}$

V.

\section{The Application of the FSIA Does Not AfFect Antecedent Substantive Rights}

As described above, Landgraf presented two steps for the court to determine if a statute has a retroactive effect: first, whether Congress expressly indicated that the new statute was or was not to be applied retroactively, and second, "whether the new statute would have retroactive effect, i.e., whether it would impair rights a party possessed when he acted, increase a party's liability for past conduct, or impose new duties with respect to transactions already completed."287 This article will discuss these steps in reverse order, because the evidence regarding whether or not the FSIA has a retroactive effect is much stronger than the evidence of congressional intent as to whether the statute was designed to operate retroactively.

Landgraf stated that "[e]ven absent specific legislative authorization, application of new statutes passed after the events in suit is unquestionably proper in many situations," 288 and that a statute does not operate retrospectively, and thus impermissibly, "merely because it is applied in a case arising from conduct antedating the statute's enactment or upsets expectations based in prior law."289 Rather, according to Landgraf, "the court must ask whether the new provision attaches

285. See supra text accompanying notes $251-253$.

286. Ironically, the Abrams court did just that by applying the FSIA and Dole Food to the issue of the sovereign status of the French railroad company as of the filing of the suit. The court determined that the entity was a majority state-owned entity under 28 U.S.C. $\$ 1603$ (b) at the time of filing, and thus was eligible for the immunity provisions of the FSIA. Abrams v. Société Nationale des Chemins de Fer Français, 332 F.3d 173, 180-81 (2d Cir. 2003).

287. Landgraf v. USI Film Prods., 511 U.S. 244, 280 (1994).

288. Id. at 273 .

289. Id. at 269 (citation omitted). 
new legal consequences to events completed before its enactment," and must consider "the nature and extent of the change in the law and the degree of connection between the operation of the new rule and a relevant past event."290 Quoting Justice Story, the court continued: "[E]very statute, which takes away or impairs vested rights acquired under existing laws, or creates a new obligation, imposes a new duty, or attaches a new disability, in respect to transactions or considerations already past, must be deemed retrospective."291

By contrast, statutes that confer or deny jurisdiction or change procedural rules may be applied in suits arising before their enactment without raising concerns about retroactivity. ${ }^{292}$ The Supreme Court reviewed several cases involving procedural or remedial changes that were held not to affect antecedent rights in an impermissible way:

In Thorpe, we held that an agency circular requiring a local housing authority to give notice of reasons and opportunity to respond before evicting a tenant was applicable to an eviction proceeding commenced before the regulation issued. Thorpe shares much with both the "procedural" and "prospective-relief" cases. Thus, we noted in Thorpe that new hearing procedures did not affect either party's obligations under the lease agreement between the housing authority and the petitioner, and, because the tenant had "not yet vacated," we saw no significance in the fact that the housing authority had "decided to evict her before the circular was issued." The Court in Thorpe viewed the new eviction procedures as "essential to remove a serious impediment to the successful protection of constitutional rights. ..."

Like the new hearing requirement in Thorpe, the attorney's fee provision at issue in Bradley did not resemble the cases in which we have invoked the presumption against statutory retroactivity. Attorney's fee determinations, we have observed, are "collateral to

290. Id. at $269-70$.

291. Id. at 269 (quoting Soc'y for Propagation of the Gospel v. Wheeler, 22 F. Cas. 756,767 (C.C.D.N.H. 1814) (No. 13,156) (Story, J.)).

292. Id. at 274-75.

Changes in procedural rules may often be applied in suits arising before their enactment without raising concerns about retroactivity. . . Because rules of procedure regulate secondary rather than primary conduct, the fact that a new procedural rule was instituted after the conduct giving rise to the suit does not make application of the rule at trial retroactive.

Id. at 275 (citation omitted) (footnote omitted). 
the main cause of action" and "uniquely separable from the cause of action to be proved at trial." 293

Sovereign immunity determinations, similarly, are collateral to the main cause of action and are separable from the cause of action to be proved at trial. At most, the FSIA may be viewed as removing certain impediments to the successful prosecution of rights, such as the difficulties of serving process on foreign sovereigns ${ }^{294}$ and executing on judgments obtained against foreign sovereigns, ${ }^{295}$ which are procedural and remedial effects that are not impermissibly retroactive in nature. The immunity provisions are procedural and jurisdictional provisions that affect where and how suits against a foreign sovereign may be brought, but do not create a competent forum where none existed before, because United States courts consistently have held that federal courts have the power to adjudicate claims against foreign sovereigns. The determination of immunity is a collateral determination, separable from the merits of the suit, that addresses whether the court should refrain from exercising its power based on the circumstances at the time of filing of the action.

The Supreme Court has held that the FSIA was not intended to affect substantive law concerning the rights of foreign states. ${ }^{296} \mathrm{Sec}-$ tion 1606 of the FSIA provides that "[a]s to any claim for relief with respect to which a foreign state is not entitled to immunity ..., the foreign state shall be liable in the same manner and to the same extent as a private individual under like circumstances . . ."297 The legislative history of the FSIA confirms this fact:

The bill is not intended to affect the substantive law of liability. Nor is it intended to affect ... the attribution of responsibility between or among entities of a foreign state; for example, whether the proper entity of a foreign state has been sued, or whether an entity sued is liable in whole or in part for the claimed wrong. ${ }^{298}$

293. Id. at 276-77 (citing Thorpe v. Hous. Auth. of Durham, 393 U.S. 268 (1969); Bradley v. Sch. Bd. of Richmond, 416 U.S. 696 (1974)) (citations omitted) (footnote omitted).

294. 28 U.S.C. $\S 1608(2000)$.

295. 28 U.S.C. $\S 1610(2000)$.

296. First Nat'l City Bank v. Banco Para el Comercio Exterior de Cuba, 462 U.S. 611, 620-21 (1983) ("The language and history of the FSIA clearly establish that the Act was not intended to affect the substantive law determining the liability of a foreign state or instrumentality, or the attribution of liability among instrumentalities of a foreign state.").

297. 28 U.S.C. $\S 1606$ (2000).

298. H.R. REP. No. 94-1487, at 12 (1976), reprinted in 1976 U.S.C.C.A.N. 6604, 6610 . 
The FSIA did not create a new federal cause of action, but did remove certain impediments to existing federal causes of action under diversity jurisdiction, admiralty jurisdiction, Alien Tort Act claims, or other federal jurisdictional statutes. ${ }^{299}$ The major change intended and accomplished by the FSIA was to remove the case by case decisionmaking authority as to sovereign immunity from the executive branch and place it with the judicial branch. ${ }^{300}$ The FSIA also codified the existing law of sovereign immunity, and in so doing, clarified the terms under which foreign sovereigns would and would not enjoy immunity. ${ }^{301}$ If anything, these changes did not divest foreign states of settled expectations; instead, they clarified unsettled and uncertain expectations as to whether the state of relations between the foreign state and the United States at the time of suit would prompt the State Department to take a position in favor of immunity in a given matter, or whether the foreign state would have to subject itself to the power of the court in order to defend its rights.

Virtually every court that has addressed the issue has found that the FSIA should be applied to actions whose operative facts predate the effective date of the Act in January 1977, so long as the facts postdate the 1952 Tate Letter. ${ }^{302}$ It is tempting to speculate on why the courts might find that an impermissible retroactive effect of the

299. The D.C. Circuit observed in Gilson v. Republic of Ireland:

While [the] FSIA was by all accounts an important piece of legislation, it is a great exaggeration to say that plaintiff was without remedy before it became effective. . . . It may be true . . . that the Act curtailed the possibility of the Department of State intervening here with its own plea of sovereign immunity for the defendants, removed certain procedural obstacles, and increased the property available to plaintiff for judgment. But to say that any action was effectively barred before FSIA is not true.

682 F.2d 1022, 1025 (D.C. Cir. 1982); see also Turkmani v. Republic of Bolivia, 193 F. Supp. 2d 165, 173-74 (D.D.C. 2002).

300. Amerada Hess Shipping Corp. v. Argentine Republic, 830 F.2d 421, 426-27 (2d Cir. 1987).

301. Id. at 427.

302. See, e.g., Carl Marks \& Co. v. Union of Soviet Socialist Republics, 841 F.2d 26, 27 (2d Cir. 1988); Jackson v. People's Republic of China, 794 F.2d 1490, 1497 (11th Cir. 1986); Turkmani, 193 F. Supp. 2d at 174; Djordjevich v. Bundesminister der Finanzen, Fed. Republic of Germany, 827 F. Supp. 814, 817 (D.D.C. 1993), aff'd, 124 F.3d 1309 (D.C. Cir. 1997); Slade v. United States of Mexico, 617 F. Supp. 351, 355-58 (D.D.C. 1985), aff'd, 790 F.2d 163 (D.C. Cir. 1986); see also cases cited supra notes 241-242. The holdouts cited earlier, Amoco Overseas and Corporacion Venezolana, are questionable in light of later decisions of the Second Circuit, namely Carl Marks and Abrams. See Amoco Overseas Oil Co. v. Compagnie Nationale Algerienne de Navigation, 605 F.2d 648, 653-54 (2d Cir. 1979); Corporacion Venezolana de Fomento v. Vintero Sales Corp., 629 F.2d 786, 790-91 (2d Cir. 1980); Carl Marks, 841 F.2d 26; Abrams v. Société Nationale des Chemins de Fer Français, 332 F.3d 173 (2d Cir. 2003); supra notes 266-267 and accompanying text. 
FSIA apparently does not kick in until the operative facts are twentyfive years old or older. Giving these courts the benefit of the doubt, their holdings rest on the perception that the 1952 Tate Letter confounded otherwise settled expectations of complete and absolute immunity from suit in the United States, which had risen to the level of antecedent rights, so that only after 1952 , would a foreign sovereign expect to be haled before a U.S. court for private activities. ${ }^{303}$ This interpretation misreads the history of sovereign immunity in the United States in the twentieth century prior to 1952.

The FSIA did not remove antecedent rights enjoyed by foreign states prior to the Tate Letter. ${ }^{304}$ Nothing in the history of the law and practice of sovereign immunity would indicate to a foreign sovereign that it was entitled to enjoy immunity from suit within the territory of another sovereign; in contrast, the courts and executive branch constantly reiterated that the jurisdiction of United States courts was waived as an exercise of comity for the promotion of good foreign policy and international relations. ${ }^{305}$ If anything, a foreign state should only have felt a right to request immunity through a properly sanctioned channel; the United States' practice and interpretation of the classical and restrictive theories of sovereign immunity before and after the 1952 Tate Letter would not have confirmed any absolute entitlement to immunity from suit with regard to "private" actions of the sovereign. Thus, the FSIA does not have an impermissible retroactive effect when applied to actions whose operative facts predate the statute's effective date and predate the 1952 Tate Letter.

VI.

CONGRESS INTENDED THE FSIA

to Apply Retroactively

According to Landgraf,

[T] he court's first task is to determine whether Congress has expressly prescribed the statute's proper reach. If Congress has done so, of course, there is no need to resort to judicial default rules. When, however, the statute contains no such express command, the court must determine whether the new statute would have retroactive effect . . . 306

303. Carl Marks, 841 F.2d at 27; Jackson, 794 F.2d at 1497-98; Garb v. Republic of Poland, 207 F. Supp. 2d 16, 30 (E.D.N.Y. 2002).

304. See cases cited supra note 270.

305. See Princz v. Fed. Republic of Germany, 26 F.3d 1166, 1170 (D.C. Cir. 1994).

306. Landgraf v. USI Film Prods., 511 U.S. 244, 280 (1994). 
Lindh v. Murphy elaborated on Landgraf, holding that the normal rules of construction generally apply when a court determines the temporal reach of a statute. ${ }^{307}$ However, if Congress is to be regarded as intending a retroactive effect to a civil statute, the command or directive to apply the statute retroactively must be "clear" and "express."308

In Lindh, an amendment to the habeas corpus statute was held to be inapplicable to non-capital cases pending at the time of the amendment's enactment. ${ }^{309}$ The Supreme Court noted that a simultaneouslyenacted provision on capital cases expressly required application to then-pending cases, and reasoned that this express requirement, by negative implication, showed that the amendments pertinent to noncapital cases were meant to apply only to cases filed after the amendments' enactments. ${ }^{310}$

The converse of this situation occurs in the FSIA. The FSIA expressly provides that "property in the United States of a foreign state, as defined in section 1603(a) of this chapter, used for a commercial activity in the United States, . . . shall not be immune from attachment ... after the effective date of this Act . . .."311 This prospective language occurs only in section 1610 , not in the provisions of the FSIA regarding 28 U.S.C. $\S \S 1330,1602-09$, and 1611 . Thus, by negative implication as described in Lindh, Congress intended these other sections to have a retrospective application. ${ }^{312}$

Other courts have found an implication of retroactivity in the language of various sections of the FSIA. In declaring the purpose of the FSIA, Congress directed that "[c]laims of foreign states to immunity should henceforth be decided by courts of the United States and of the States in conformity with the principles set forth in this chapter."313 The Princz court found that this statement of purpose suggested that Congress intended the FSIA apply to all cases decided after its enactment, regardless of when the plaintiff's cause of action actually accrued. ${ }^{314}$ However, other courts have drawn the opposite conclusion,

307. 521 U.S. 320,326 (1997).

308. Id. at $325-26$.

309. Id. at 326-27.

310. Id.

311. 28 U.S.C. $\$ 1610(2000)$.

312. Yessenin-Volpin v. Novosti Press Agency, 443 F. Supp. 849 (S.D.N.Y. 1978), and Nat'l Am. Corp. v. Fed. Republic of Nigeria, 448 F. Supp. 622, 638-39 (S.D.N.Y. 1978 ), applied the jurisdictional provisions of the FSIA actions pending on the effective date, on the basis that the "after the effective date" language appearing in 28 U.S.C. $\$ 1610$ and not in 28 U.S.C. $\S \S 1330,1602$, and 1608 indicated that these latter sections may have been intended by Congress to have retroactive application. 313. 28 U.S.C. $\$ 1602$.

314. Princz v. Fed. Republic of Germany, 26 F.3d 1166, 1170 (D.C. Cir. 1994). 
finding that the "henceforth" language indicates a prospective intention. ${ }^{315}$

In addition, a message of retroactivity has been discerned in the design of the FSIA. When it enacted the FSIA, Congress deleted from 28 U.S.C. $\S 1332$ the provision for diversity jurisdiction over suits brought by a United States citizen against a foreign government. According to the legislative history, "[s]ince jurisdiction in actions against foreign states is comprehensively treated by the new section 1330, a similar jurisdictional basis under section 1332 becomes superfluous."316 The Princz court held that:

Unless one is to infer that the Congress intentionally but silently denied a federal forum for all suits against a foreign sovereign arising under federal law that were filed after enactment of the FSIA but based upon pre-FSIA facts, the implication is strong that all questions of foreign sovereign immunity, including those that involve an act of a foreign government taken before 1976, are to be decided under the FSIA. ${ }^{317}$

Although persuasive, these arguments based on the structure and language of the FSIA are not as compelling as the fact that the FSIA codified the law of sovereign immunity in the United States. That law had held that determinations of immunity are to be made at the time of filing of the suit on a case-by-case basis, based on facts that are properly submitted to the court through official channels, and in light of the notice given to foreign states through the public announcements of the State Department and the executive branch's suggestions of immunity made during the course of the suit. In that judicial determinations naturally have a retroactive application with respect to the parties in the litigation and regarding any other similarly situated parties in pending or future cases bound through stare decisis by the judicial determination, Congress adopted and codified a system that was inher-

315. As evidence of the FSIA's prospective reach, these courts have focused on both the "henceforth" language of 28 U.S.C. $\S 1602$ and Congress' decision to delay the effective date of the FSIA for ninety days. Pub. L. No. 94-583, § 8, 90 Stat. 2891, 2898 (1976); see Slade v. United States of Mexico, 617 F. Supp. 351, 357 (D.D.C. 1985), aff'd, 790 F.2d 163 (D.C. Cir. 1986); Jackson v. People's Republic of China, 596 F. Supp. 386, 388 (N.D. Ala. 1984), aff'd, 794 F.2d 1490 (1 lth Cir. 1986). Carl Marks asserted that the provision in 28 U.S.C. $\$ 1330$ (a) that district courts "shall have" jurisdiction over cases specified in 28 U.S.C. $\$ \$ 1605$ and 1607 indicates an intention for the statute to have prospective application. Carl Marks v. Union of Soviet Socialist Republics, 665 F. Supp. 323, 336-37 (S.D.N.Y. 1987), aff'd, 841 F.2d 26 (2d Cir. 1988).

316. H.R. REP. No. 94-1487, at 14 (1976), reprinted in 1976 U.S.C.C.A.N. 6604, 6613.

317. Princz, 26 F.3d at 1170 (citation omitted). 
ently retroactive. In the absence of clear language, such as the express prospective language found in section 1610 of the Act that the remainder of the FSIA was not to have retroactive effect, the FSIA should be construed to apply to conduct that predates the 1952 Tate Letter.

\section{VII. \\ Evaluating Nazi Germany's Expectations of Absolute IMmunity for War Crimes}

If the foregoing arguments were to fail, and courts were to determine that the FSIA cannot be applied generally to actions whose operative facts occurred prior to 1952, there remains an argument that the particular situation of the Nazi war crimes dictates that Germany has no antecedent right to immunity that would be affected by an application of the FSIA to lawsuits arising from these crimes. This last argument for application of the FSIA to World War II-era war crimes involves an analysis of the reasonable expectations of Nazi Germany and its agencies and instrumentalities that they would receive absolute immunity from the jurisdiction of United States courts. Nazi Germany maintained these expectations despite three crucial facts: (1) Germany was engaged in war with the United States at the time of the events; (2) the State Department expressly indicated on multiple occasions that U.S. courts were to be free from any restrictions on their jurisdiction to adjudicate property claims arising from Nazi acts of plunder or Nazi-influenced property transactions; and (3) the Nazis had engaged in jus cogens violations and other acts that violated established restrictions of customary and conventional international law, which civilized nations would view as grounds to find a waiver of sovereign immunity.

First, Germany should have no expectation of sovereign immunity from the jurisdiction of United States courts during wartime. From the beginning, United States authorities indicated that immunity should be extended to "friendly" foreign sovereigns only; 318 obviously, an active belligerent engaged in armed conflict against the United States is not a friendly foreign sovereign, as revealed by the treatment of belligerent powers in actions arising from wars in which the United States was involved. ${ }^{319}$

318. E.g., Republic of Mexico v. Hoffman, 324 U.S. 30, 34-35 (1945); Ex parte Peru, 318 U.S. 578, 588-89 (1943); The Santissima Trinidad, 20 U.S. (7 Wheat.) 283, 352-53 (1822); The Schooner Exchange v. McFaddon, 11 U.S. (7 Cranch) 116, 144 (1812); The Johnson Lighterage Co. No. 24, 231 F. 365, 368 (D.N.J. 1916).

319. See cases cited supra note 45. 
Second, beyond the simple fact that a belligerent state engaged in armed conflict against the United States should not expect to receive immunity from the jurisdiction of the courts of the United States, the State Department and executive branch of the United States made it very clear on several occasions during and after World War II that U.S. courts would entertain suits arising from acts of Nazi plunder, looting, and discriminatory expropriation perpetrated against people under their domination and control. ${ }^{320}$ Sovereign immunity may be withdrawn by giving notice, and the Nazi regime was given notice on several occasions that immunity would not be extended to preclude the redress in municipal courts of the United States of war crimes involving the property of subject peoples. ${ }^{321}$

Finally, there is the argument that the Nazis forfeited their rights, if any, to sovereign immunity based on their perpetration of jus cogens violations and other violations of firmly established restrictions of customary and conventional international law. This argument was eloquently made by Judge Wald of the District of Columbia Circuit in her dissenting opinion in Princz, ${ }^{322}$ in which she stated:

In the mid-1940s, Germany could not, even in its wildest dreams, have expected the executive branch of the United States, as a matter of grace and comity, to suggest immunity for its enslavement and confinement (in three concentration camps) of an American citizen during the Holocaust. The outcome of the Nuremberg trials provides a clear signal that the international community, and particularly the United States-one of the four nations that established the Nuremberg Tribunal-would not have supported a broad enough immunity to shroud the atrocities committed during the Holocaust. Indeed, the Nuremberg Tribunal denied the German defendants' claims of official immunity because in the eyes of the international community Germany as a whole was owed no immunity: "[h]e who violates the laws of war cannot obtain immunity while acting in pursuance of the authority of the state if the state in authorizing action moves outside its competence under International Law." Clearly, had the question been put to them, the United States executive branch would have opted to deny Germany's claims to immunity for the crimes alleged in this case. ${ }^{323}$

Judge Wald's cogent explanation of the international law implications of Nazi Germany's jus cogens violations needs no further illumination. In Altmann II, the Ninth Circuit found Wald's rationale to

320. See supra text accompanying notes $142-147$

321. Id.

322. 26 F.3d 1166, 1176-85 (D.C. Cir. 1994) (Wald, J., dissenting).

323. Id. at 1179 (citations omitted) (alteration in original). 
be entirely persuasive, and adopted it in support of that court's decision to apply the FSIA to a case involving the plunder of art work prior to and during World War II. ${ }^{324}$

\section{VIII. \\ CONCLUSION}

The FSIA should be construed as a jurisdictional statute whose terms apply to actions arising from operative facts that arose prior to the effective date of the Act, regardless of whether these facts also occurred prior to the 1952 Tate Letter. The Tate Letter reaffirmed the State Department's intent to follow the restrictive theory of sovereign immunity in actions filed in United States courts, and the FSIA codified that practice. The Supreme Court in Dole Food already has construed the FSIA as a jurisdictional statute, and as such, applied the facts and circumstances concerning the foreign sovereign's claim to immunity that existed at the time of filing of the action, not the facts and circumstances at the time when the operative facts occurred. When construed as a jurisdictional statute, as directed by the Supreme Court in Dole Food, the FSIA does not present any retroactivity issues.

The FSIA satisfies the second step of the Landgraf analysis, because the FSIA does not have an impermissible retroactive effect that upsets vested, antecedent rights of the parties. The FSIA does not affect the substantive causes of action, defenses, and liabilities of parties concerning the merits of actions that predate or postdate the Tate Letter, and merely effects certain procedural changes that remove obstacles to the enforcement of plaintiffs' rights. Furthermore, to the extent that a foreign state might have reasonably expected to receive immunity from suits filed during the pre- 1952 time period when the United States' adherence to the restrictive theory of immunity was more uncertain - an expectation that the FSIA either confirms or rebuts depending on the public or private nature of the sovereign's acts-this must be viewed as the type of wishful thinking based on an existing legal climate that is disregarded upon the enactment of a procedural or remedial statute that changes the legal climate. It is akin to situations discussed in Landgraf wherein a new property tax or zoning regulation upsets the reasonable expectations that prompted those affected to acquire property, or a new law banning gambling harms a person who had either begun to construct a casino before the law's

324. Altmann v. Republic of Austria, 317 F.3d 954, 963 (9th Cir. 2002). 
enactment or spent his life learning to count cards. ${ }^{325}$ A foreign sovereign's expectation that it will receive the privilege of sovereign immunity never has been, and never should be, viewed as an antecedent right. Only statutes that affect the merits of the parties' claims and defenses against each other by taking away or impairing vested rights established under existing laws, or creating new obligations, imposing new duties, or attaching new disabilities in respect to transactions or considerations that are already past, may be deemed to be retrospective. ${ }^{326}$

The most compelling evidence that Congress intended the FSIA to apply to events predating the statute is the fact that the Act expressly states that it codifies the existing law of sovereign immunity as practiced in the United States. Determinations of immunity were made at the time of filing of the suit on a case-by-case basis, based on facts that were properly submitted to the court through official channels, and in light of the notice given to foreign states during the course of the suit through the public announcements of the State Department and the executive branch's suggestions of immunity. In that judicial determinations naturally have a retroactive application with respect to the parties in the litigation and regarding any other similarly situated parties in pending or future cases bound through stare decisis by the judicial determination, Congress adopted and codified a system that was inherently retroactive.

Consideration of the issue of retroactivity with respect to World War II-era war crimes must also include the fact that Nazi Germany and its agencies and instrumentalities should have had no reasonable expectation of immunity from suit. Belligerent powers do not enjoy the immunities of friendly states in the territorial courts of the enemy. The United States and the other allied powers made abundantly clear, both in official communications during the war and in the Nuremberg prosecutions after, that no restrictions would be placed on U.S. courts' ability to adjudicate claims arising from the Nazis' plundering and pillaging of Europe.

Therefore, the FSIA should be applied to provide jurisdiction over Nazi war crimes of plunder and expropriation.

325. Landgraf v. USI Film Prods., 511 U.S. 244, 270 n.24 (1994).

326. See id. at 269. 